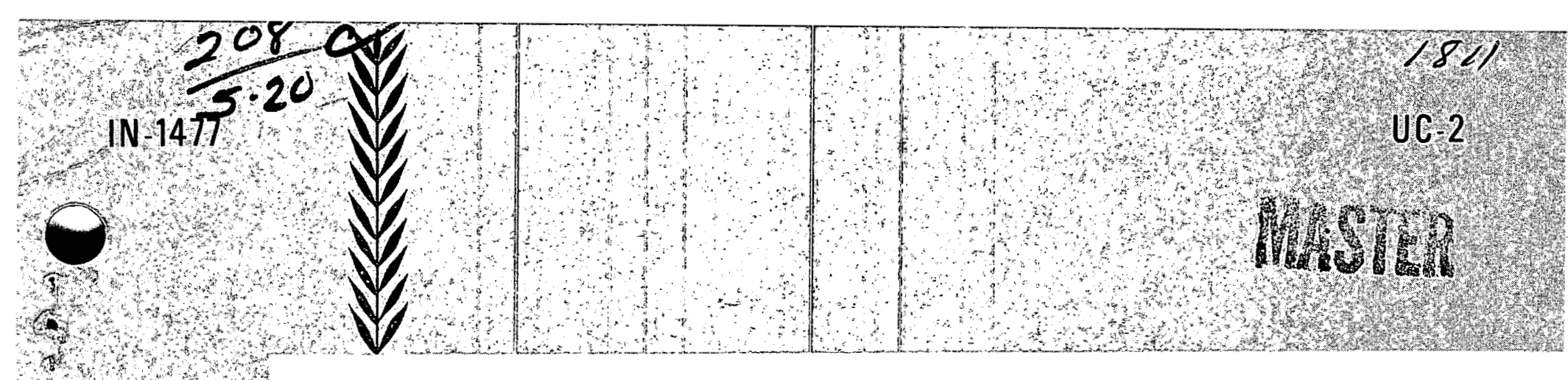

\title{
DESTRUCTIVE EXAMINATION OF A HALLAM NUCLEAR POWER FACILITY INTERMEDIATE \\ HEAT EXCHANGER
}

\author{
W.L. RANDOM
}

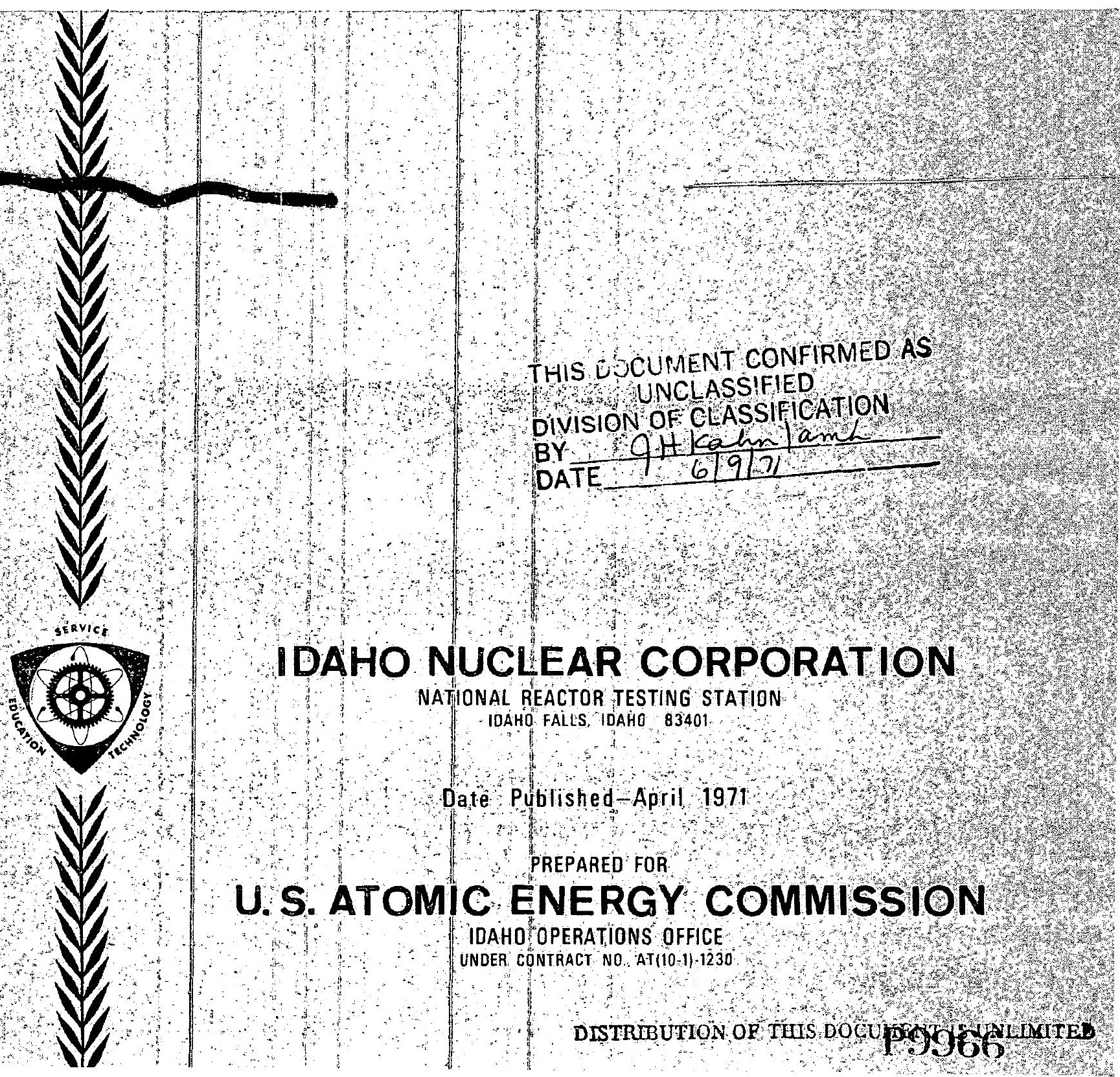




\section{DISCLAIMER}

This report was prepared as an account of work sponsored by an agency of the United States Government. Neither the United States Government nor any agency Thereof, nor any of their employees, makes any warranty, express or implied, or assumes any legal liability or responsibility for the accuracy, completeness, or usefulness of any information, apparatus, product, or process disclosed, or represents that its use would not infringe privately owned rights. Reference herein to any specific commercial product, process, or service by trade name, trademark, manufacturer, or otherwise does not necessarily constitute or imply its endorsement, recommendation, or favoring by the United States Government or any agency thereof. The views and opinions of authors expressed herein do not necessarily state or reflect those of the United States Government or any agency thereof. 


\section{DISCLAIMER}

Portions of this document may be illegible in electronic image products. Images are produced from the best available original document. 
Printed in the United States of America Available from

National Technical Information Service

U. S. Department of Conmerce

5285 Port Royal Road

Springfield, Virginia 22151

Price: Printed Copy $\$ 3.00$; Microfiche $\$ 0.95$

\section{LEGAL NOTICE}

This report was prepared as an account of wark sponsored by the United States Government. Neither the United States nor the United States Atomic Energy Commission, nor any of their employees, nor any of their contractors, subcontractors, or their employees, makes any warranty, express or implied. or assumes any legal liability or responsibility for the accuracy, completeness or usefulness of any information, apparatus, product or process disclosed, or represents that its use would not infringe privately owned rights. 
This report was prepared as an account of work sponsored by the United States Government. Neither the United States nor the United States Atomic Energy Commission, nor any of their employees, nor any of their contractors, subcontractors, or their employees, makes any warranty, express or implied, or assumes any legal liability or responsibility for the accuracy, completeness or usefulness of any information, apparatus, product or process disclosed, or represents that its use would not infringe privately owned rights.

DESTRUCTIVE EXAMTNATION OF A HALLAM NUCLEAR POWER FACILITY INTERMEDIATE HEAT EXCHANGER

BY

W. L. Random

\section{IDAHO NUCLEAR CORPORATION}
A Jointly Owned Subsidiary of
AEROJET GENERAL CORPORATION ALLIED CHEMICAL CORPORATION PHILLIPS PETROLEUM COMPANY

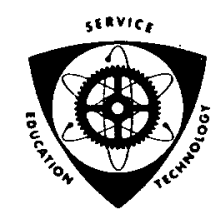

Date Published - April, 1971
This document is PUBLICLY RELEASABLE Bam Steda Authorizing Official Date: $10 / 31 / 06$

\footnotetext{
PREPARED FOR THE U. S. ATOMIC ENERGY COMMISSION

IDAHO OPERATIONS OFFICE

UNDER CONTRACT NO. AT (10-1)-1230
} 


\section{ACKNOWLEDGEMENTS}

Appreciation is expressed to the following Idaho Nuclear Corporation organizations: the TAN Operations Machine Shop, Nuclear and Operational Safety, Reliability and Quality Assurance, and Analytical Chemistry for their assistance during the disassembly and examination of the Hallam heat exchanger.

Appreciation is also extended to Mr. M. R. Martin and Technicians of the Metallurgy and Hot Cell Branch for their assistance in the metallurgical examination of the components from the disassembled heat exchanger. 


\begin{abstract}
One Hallam Nuclear Power Facility (HNPF) intermediate heat exchanger (IHX) was disassembled and the components metallurgically examined by the Idaho Nuclear Corporation at Test Area North of the AEC National Reactor Testing Station, located near Idaho Falls, Idaho. The major objective of the examination was to provide data for assessment of crevice corrosion problems and evaluation of operational deterioriations associated with front-face type tube-to-tubesheet weld joints for sodium-to-sodium heat exchangers. Metallurgical evaluation of the front face tube-to-tubesheet welds found the welds to be structurally sound. The presence of sodium in the tube-totubesheet crevice did not damage the tubes or the tubesheet since no correlation was found between sodium deposits in the crevices and tube or tubesheet ligament cracks. The examination revealed stress corrosion cracking in some tubes and ligaments of the top tubesheet but not in the bottom tubesheet.
\end{abstract}




\section{CONTENTS}

ACKNOWLEDGEMENTS............................. ii

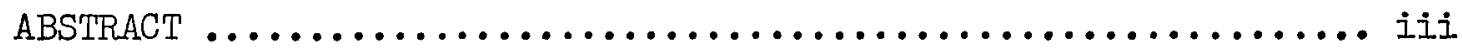

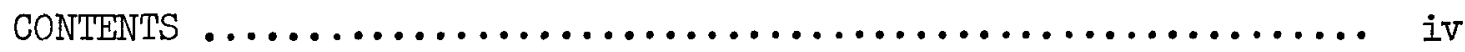

FIGURES $\ldots \ldots \ldots \ldots \ldots \ldots \ldots \ldots \ldots \ldots \ldots \ldots \ldots \ldots \ldots \ldots \ldots \ldots \ldots \ldots$

TABLES $\ldots \ldots \ldots \ldots \ldots \ldots \ldots \ldots \ldots \ldots \ldots \ldots \ldots \ldots \ldots \ldots \ldots \ldots \ldots \ldots \ldots \ldots \ldots \ldots$

CONCLUSION $\ldots \ldots \ldots \ldots \ldots \ldots \ldots \ldots \ldots \ldots \ldots \ldots \ldots \ldots \ldots \ldots \ldots \ldots$ vii

INTRODUCTION $\quad \ldots \ldots \ldots \ldots \ldots \ldots \ldots \ldots \ldots \ldots \ldots \ldots \ldots \ldots \ldots \ldots \ldots \ldots$

I. PREPARATIONS FOR DISASSEMBLY $\ldots \ldots \ldots \ldots \ldots \ldots \ldots \ldots \ldots$

1. Examination Plan and Quality Assurance ........... 2

2. IHX Identification $\ldots \ldots \ldots \ldots \ldots \ldots \ldots \ldots \ldots \ldots \ldots \ldots$

3. IHX Selection $\ldots \ldots \ldots \ldots \ldots \ldots \ldots \ldots \ldots \ldots \ldots \ldots \ldots$

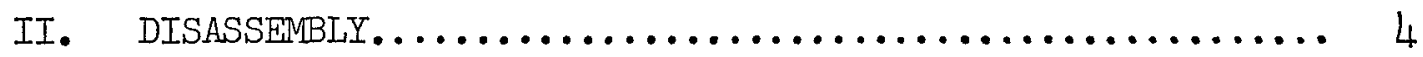

III. VISUAL OBSERVATIONS $\ldots \ldots \ldots \ldots \ldots \ldots \ldots \ldots \ldots \ldots \ldots \ldots \ldots$

IV. NON-DESTRUCTIVE TESTING AND RESULTS $\ldots \ldots \ldots \ldots \ldots \ldots \ldots \ldots$

1. Radiation Surveys ......................... 13

2. Non-Destructive Tests .................... 13

V. DESTRUCTIVE EXAMTINATION AND RESULTS ............. I7

1. Tube-to-Tubesheet Welds ....................... 17

2. Tubes and Tubesheet $\ldots \ldots \ldots \ldots \ldots \ldots \ldots \ldots \ldots \ldots \ldots$

3. Tube-to-Tubesheet Crevice $\ldots \ldots \ldots \ldots \ldots \ldots \ldots \ldots \ldots . \ldots 22$

4. Sections at Baffles .................... 23

APPENDIX A - - RELIABILITY \& QUALITY ASSURANCE

INSPECTION REPORTS ......................... 29

APPENDIX B -- PIANNING DOCUMENTS $\ldots \ldots \ldots \ldots \ldots \ldots \ldots \ldots \ldots \ldots \ldots$ 
1. Unit IA ready for diassembly $\ldots \ldots \ldots \ldots \ldots \ldots \ldots \ldots \ldots \ldots, 5$

2. Removing top head with the "Fein" pipe saw $\ldots \ldots \ldots \ldots \ldots .6$

3. Making final cut to remove top head $\ldots \ldots \ldots \ldots \ldots \ldots \ldots \ldots, 7$

4. Internal surfaces immediately after top head removal ...... 7

5. Required cut through the secondary nozzles to remove

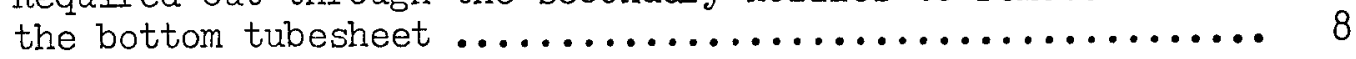

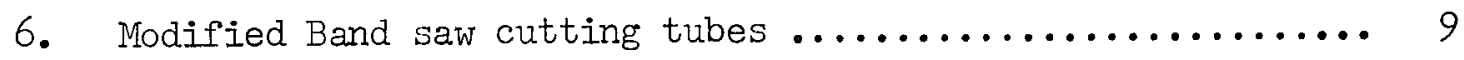

7. Removing the bottom tubesheet with the "Fein" pipe saw ..... 9

8. Bottom tubesheet showing sodium deposit on secondary side .. 10

9. Secondary side of vessel with a portion of the tubes

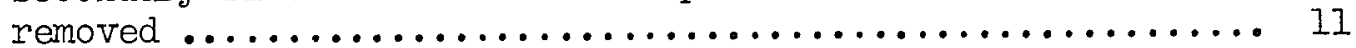

10. Sodium deposits at tube-to-tubesheet crevice $\ldots \ldots \ldots \ldots \ldots .12$

11. Location of samples removed from top tubesheet ........... 15

12. Location of samples removed from bottom tubesheet ........ 16

13. Samples as they were removed from tubesheet $\ldots \ldots \ldots \ldots \ldots$.... 18

14. Typical sample configuration $\ldots \ldots \ldots \ldots \ldots \ldots \ldots \ldots \ldots \ldots \ldots$

15. Photomicrographs of typical tube-to-tubesheet welds examined from the top tubesheet. A. Row 17 Thabe 20 Mag. $60 x \ldots \ldots \ldots \ldots \ldots \ldots \ldots \ldots . .19$

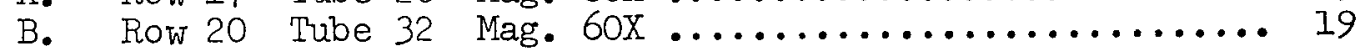

16. Photomicrographs of typical short tube tube-to-tubesheet welds examined from the top tubesheet. A \& B. Row 17 Tube 19 Mag. $60 \mathrm{X} \ldots \ldots \ldots \ldots \ldots \ldots \ldots . . .20$

17. Photomicrographs of typical tube-to-tubesheet welds examined from the bottom tubesheet. A \& B. Row 28 Tube 7 Mag. 60X

18. Photomicrographs of effective tube rolling in the bottom tubesheet.

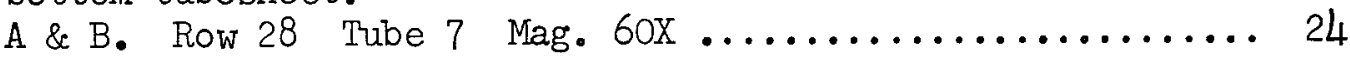

19. Photomicrographs of ineffective tube rolling in the top tubesheet. A \& B. Row 19 Tube 19 Mag. 60X 


\section{FIGURES}

20. Photomicrographs of cracked tube from top tubesheet.

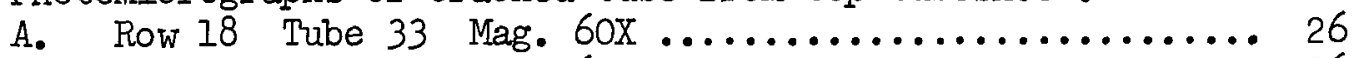

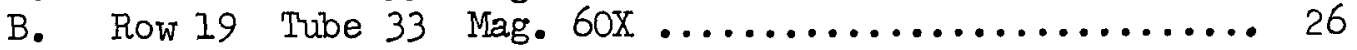

21. Photomicrographs of cracking found in top tubesheet in area of row 33 , tube 17 . Mag. $60 \mathrm{X} \ldots \ldots \ldots \ldots \ldots \ldots \ldots . \ldots . \ldots 27$

22. Sodium in the tube-to-tubesheet crevice .............. 28

\section{TABLES}

I. Tubesheet Examinations $\ldots \ldots \ldots \ldots \ldots \ldots \ldots \ldots \ldots \ldots \ldots \ldots \ldots$ 
CONCLUSIONS

The conclusions from the examination of an HNPF-IHX and the evaluation of its operating history are listed as follows:

1. The front face tube-to-tubesheet welds were found to be structurally sound.

2. The tube rolling was not effective in transfering the tube loading to the tubesheet in most samples examined. Therefore the welds functioned as a load bearing mechanism as well as a seal. The presence of sodium in the tube-to-tubesheet crevice did not damage the tubes or the tubesheet since no correlation was found between sodium deposits in the crevices and tube or tubesheet ligament cracks.

3. The cracking found in the tubes and the ligaments of the top tubesheet were caused by stress corrosion. This conclusion is based on the following facts: (a) transgranular cracks were found in several tubes and ligaments of the top tubesheet, (b) the cracks found in the tubes were adjacent to the cracks in the tubesheet ligaments (with one exception), (c) chlorides were found in the tube-to-tubesheet crevices, and (d) the top tubesheet was at the hot, inlet end of the heat exchanger and thus experienced added thermal stresses.

We conclude that the bottom or outlet tubesheet did not fail or crack similar to the top tubesheet due to different service conditions.

4. No other evidence of operational damage was found. 
INTRODUCTION

The Metallurgy and Hot Cell Branch of the Idaho Nuclear Corporation (INC) destructively disassembled and examined one of the six intermediate heat exchangers (IHX) from the Hallam Nuclear Power Facility, Hallam, Nebraska. The disassembly and examination of the selected unit by INC was under the technical management of the Liquid Metals Engineering Center (IMEC), Canoga Park, California.

Systematic examination of the selected IHX was to provide evidence and supporting data of benefit to the FFTF Project. The major objectives of the examination were to provide data for assessing crevice corrosion problems and evaluating operational deterioriations associated with front-face type tube-to-tubesheet welded joints for sodium-to-sodium heat exchangers. An additional objective was to observe and evaluate other service associated deformation or wear. Therefore, the examination included areas other than the tube-to-tubesheet joint including: 1) tube wear at support plates, 2) evidence of vibration damage, and 3) tube bundle deformation.

The Hallam Nuclear Power Facility (HNPF) project was authorized in 1957 by the USAEC. The facility was operated by the Consumers Public Power District of Nebraska at their Sheldon Station site twenty miles south of Lincoln, Nebraska. The nominal rating of the plant was 75 Mwe with 80 Mwe expected. Plant construction was started in April, 1959, with beneficial occupancy in August, 1961.

The design power of the reactor was 240 Mwt and the heat generated was transmitted to a primary sodium system at approximately $945^{\circ} \mathrm{F}$ during power operation. The primary sodium system was divided among three primary loops each of which had two intermediate heat exchangers (IHX's) for a total of six IHX's. Each pair of IHX's had a secondary sodium loop which transmitted heat to a steam generating unit. The plant was designed to produce $710,000 \mathrm{lbs} / \mathrm{hr}$ of steam at $825^{\circ} \mathrm{F}$ and 800 psig. Sodium coolant was introduced to the primary and secondary systems in 1961 and preoperational testing was started. Criticality was achieved August 25, 1962, and full power was attained July, 1963. During power operation from July, 1963, to the last plant shutdown in October, 1964, the reactor average power was about 90 Mwt. The plant was dismantled between 1964 and 1968. The six IHX's from the HNPF have been in storage at the National Reactor Testing Station in Idaho since the plant was dismantled. 


\section{PREPARATIONS FOR DISASSEMBLY}

1. Examination Plan and Quality Assurance

An examination plan was prepared for selecting the unit to be examined, and for conducting a systematic non-destructive and destructive examination of the selected HNPF-IFX. The examination plan defined the sequence of operations, safety precautions, the number of samples to be obtained, the number of samples to be examined, and the nature of examination for each sample. Selected planning documents are included in Appendix B.

A Quality Verification Plan was prepared by the Reliability and Quality Assurance Division of INC. This plan was congruous with the examination plan to assure all activities associated with this examination were performed, documented, and controlled.

2. IHX Identification

The six intermediate heat exchangers from the Hallam Nuclear Power Facility, Hallam, Nebraska were stored at Test Area North of the National Reactor Testing Station after the power facility was dismantled. Positive identification of the units was necessary so that operational statistics could be related to the individual units. The cross reference of the M. W. Kellog serial number, M. W. Kellog identification number, Hallam Identification number and the storage tag letter of each unit are listed below.

$\begin{array}{lccc}\text { MWK } & \text { MWK } & \begin{array}{c}\text { Storage Tag } \\ \text { Letter }\end{array} & \begin{array}{c}\text { Hallam } \\ \text { ID No. }\end{array} \\ 4913 & \text { ID No. } & \text { D } & 2 B \\ 4914 & 1 & \text { A } & 2 \mathrm{~A} \\ 4915 & 1 \mathrm{~A} & \mathrm{~B} & 1 \mathrm{~A} \\ 4916 & 2 & \mathrm{C} & 1 \mathrm{~B} \\ 4917 & 2 \mathrm{~A} & \mathrm{E} & 3 \mathrm{~B} \\ 4918 & 3 & \mathrm{~F} & 3 \mathrm{~A}\end{array}$

3. IIX Selection

Liquid Metals Engineering Center (LMEC), Canoga Park, California, requested units $I \mathrm{~A}$ and $3 \mathrm{~B}$ (Hallam Identification Number) be nondestructively leak tested to determine which unit had the greatest 
leak rate between the primary and secondary sides. Unit IA had a tube failure during operation. Unit $3 B$ has 125 tubes installed during the manufacturing process which are shorter than specified by the design.

Units $I A$ and $3 B$ were moved by truck three miles from the storage area to the disassembly area. Each unit was pressurized to 5 psi with low moisture nitrogen (specifications are $99.9956 \%$ pure, < $15 \mathrm{ppm}$ moisture, and $-75^{\circ} \mathrm{F}$ dew point) on both the secondary and primary sides before moving. Both the primary and secondary sides of each unit were connected to a nitrogen purge system to preserve internal conditions upon arrival at the disassembly area.

The helium leak checks were complicated when helium was discovered in both the secondary and primary sides of both units prior to introducing any helium by Idaho Nuclear Corporation. IMEC

discovered all units had helium gas introduced to both sides prior to their removal from Hallam. Leaks were detected by determining relative amounts of helium in the primary sides before and after introducing more helium into the secondary sides. The leak check of each unit was carried out in the following manner:

\section{Unit 3B}

a. A vacuum was established on both the primary and the secondary sides of the unit.

b. Helium gas was sampled from the primary side into the leak detector. The pressure of the primary side was greater than I micron which made it necessary to throttle the sampling pressure to 0.2 micron to the leak detector (maximum operating pressure of leak detector).

c. Background helium on the primary side at the start of the test was recorded at 13,000 instrument divisions.

d. Helium was added to the secondary side.

e. The leak detector reading was 86,000 instrument divisions after 16 minutes of testing and after 18 minutes it was 100,000 instrument divisions.

No quantitative value can be ascertained for the leak in Unit 3B because the total pressure was greater than could be sampled directly by the leak detector. The leak would be greater than $1 \times 10^{-4} \frac{\text { std } c c}{\text { sec }}$ if an estimate is made as to the partial pressure sampled. 


\section{Unit IA}

a. Vacuum was established on both the primary and the secondary sides of the unit.

b. Helium gas was sampled from the primary side into the leak detector. The pressure on the primary side was 0.7 micron which made it necessary to throttle the sampling pressure to 0.2 micron to the leak detector (maximum operating pressure of leak detector).

c. Background helium on the primary side at the start of the test was recorded at 3,800 instrument divisions.

d. Helium was added to the secondary side.

e. The leak detector readings did not change after holding at this condition for 45 minutes. More helium was added to the secondary side bringing the helium pressure on the secondary side up to 9 psi.

f. No rise in the leak detector reading could be observed after waiting 1 hour and 45 minutes. A "Standard Leak" of $20.6 \mathrm{x}$ $10^{-8} \frac{\mathrm{std} \mathrm{cc}}{\mathrm{sec}}$ gave a normal sensitivity reading of 700 instrument divisions after the test.

Unit 3B was selected for disassembly and examination on the basis of the leak checks performed.

\section{DISASSEMBLY}

Portions of the modular framework, which supported the unit during operation, were removed using a cutting torch. The remaining section of the framework was left in place to support (Figure 1) the unit during disassembly. This method was used to avoid transferring the unit to some other support, which could add stresses to the vessel expansion joint.

The sheet metal covering the vessel externally was removed by cutting the bolts with a cutting torch. The electric heaters and sodium detector mounted to the sheet metal covering were removed with the sheet metal.

A "Fein" portable pipe saw was used to remove the two vessel heads and both tubesheets. This saw clamps around the vessel on a track and works its way around the vessel by a self contained drive unit while cutting is performed. It was necessary to remove the four vessel support lugs on the top and bottom heads to use this saw. The support lugs were removed by grinding with an abrasive wheel through the welds that mount the lugs to the vessel. The two inch pipe drain and vent line (to the secondary side) were removed from the vessel to make room 
for the saw to traverse around the vessel. A muber stopper was used to plug the 2 inch drain pipe openings to maintain a nitrogen purge on the secondary side of the vessel.

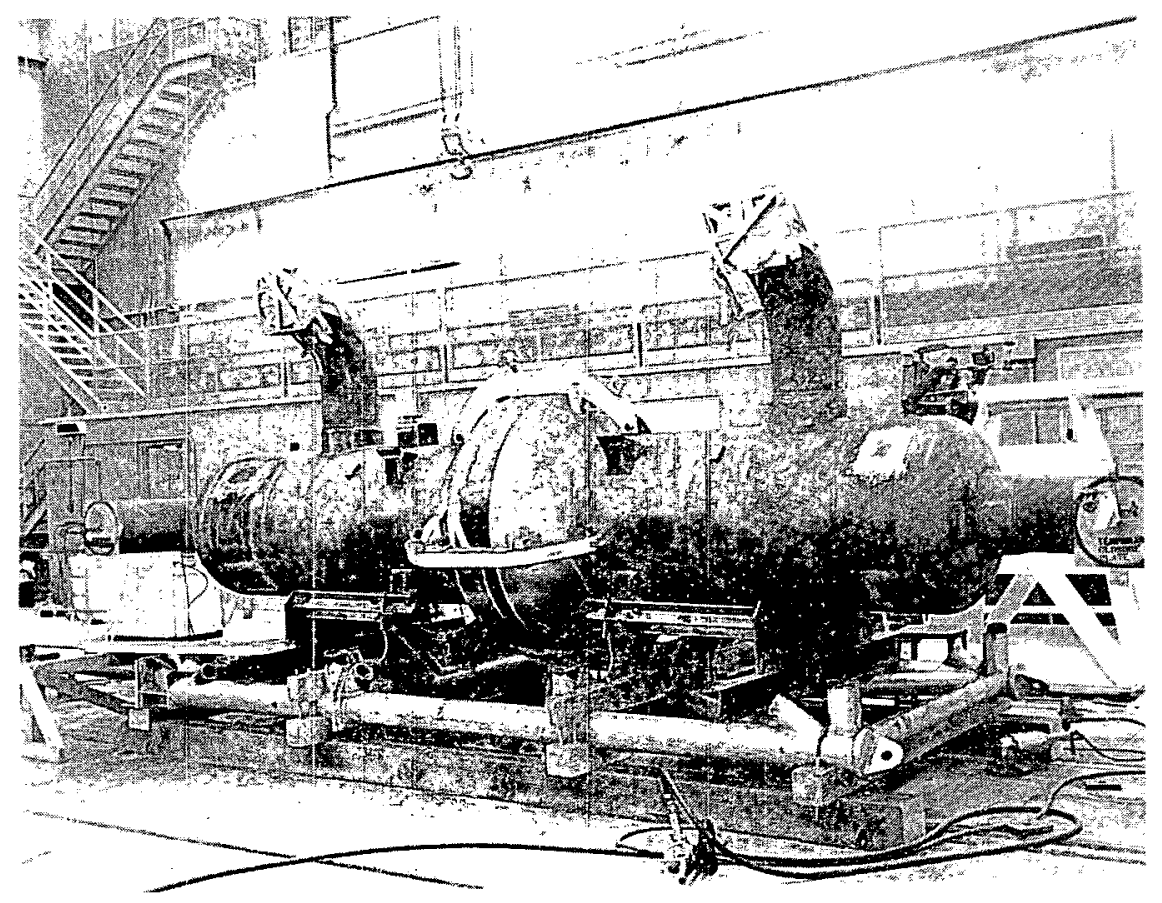

Fig. 1 Unit $1 \mathrm{~A}$ ready for disassembly

The "Fein" pipe saw was mounted on the top end of vessel (Figure 2) to remove the top head after the drain pipes were removed. Match marks were scribed on the head and the vessel before starting the cutting operations so that positive orientation of the vessel and head could be maintained after removal. The saw was tracked around the vessel to check the saw cut alignment. The first pass was a 5/8 inch deep cut using a cutting fluid. All traces of the cutting fluid were removed with acetone after the first pass. The final cut was made dry without a cutting fluid of any kind. The head was supported during and after cutting by a lug which had been welded to the head above the center of gravity.

The saw cut (Figure 3) was taped shut as the saw progressed around the vessel on the final pass. The nitrogen purge was increased to $20 \mathrm{cfh}$. These precautions were required to preserve the intermals of the vessel in the same state as they were before opening the vessel. The head was moved away from unit with an overhead crane as soon as the final cut was finished. Documentary photographs (Figure 4) which shows the tubesheet face and the intermals of the head were taken immediately after head removal. A piece of $\frac{1}{2}$ inch plexiglass was taped over the vessel opening leaving the tubesheet face visible and still maintain the 


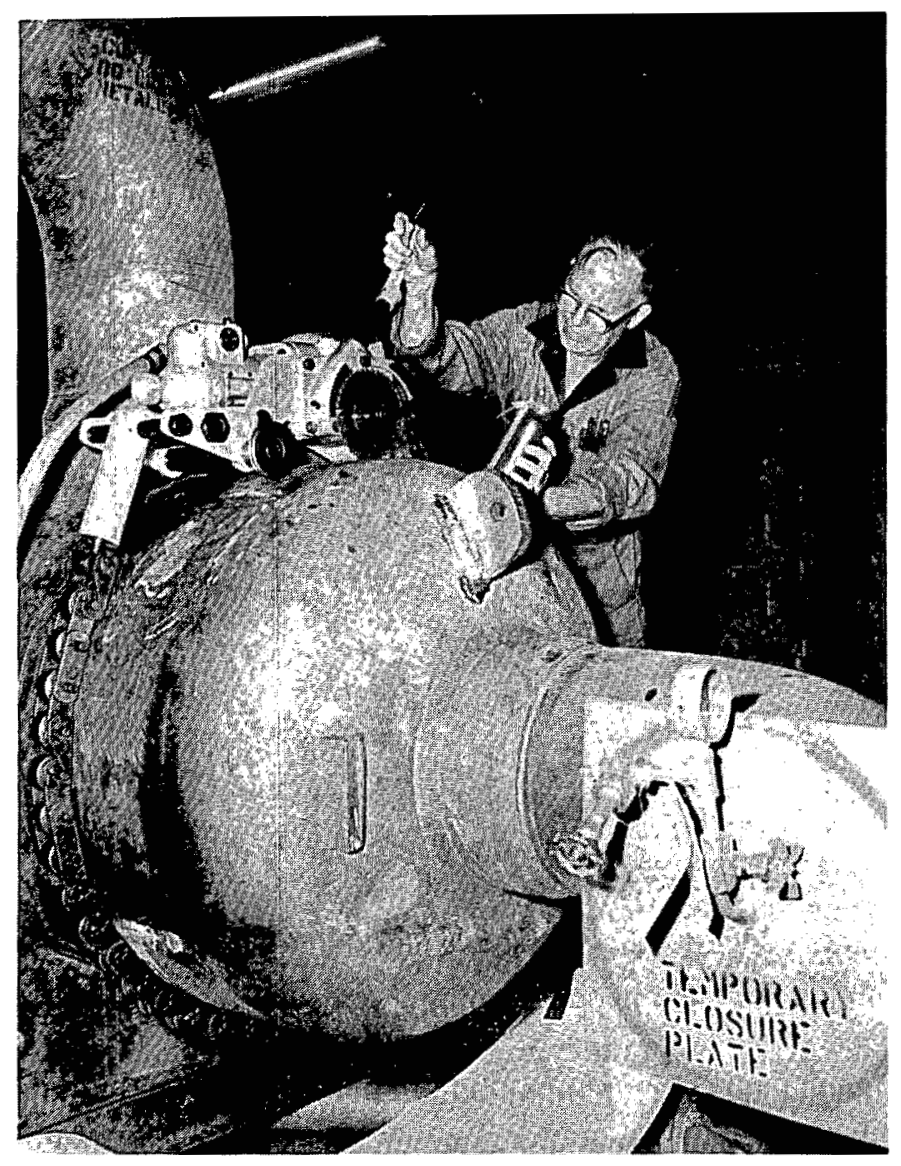

Fig. 2 Removing top head with the "Fein" pipe saw.

nitrogen atmosphere. The nitrogen flow was then reduced to $5 \mathrm{cfh}$. A double layer of .006 inch thick plastic was taped over the opening of the vessel head to protect the inside surface conditions from the atmosphere. The head was then moved to a storage area. The procedure used to remove the top head was also used to remove the bottom head.

The original examination plan called for access holes to be cut through the vessel on the secondary side just below the tubesheets. Schedule accleration was requested by LMEC and it was decided to eliminate the access holes since preliminary information could be obtained through the 14 inch secondary nozzle openings after removal.

The secondary outlet nozzle was removed with a reciprocating hack saw. This cut was made eight inches from the vessel. In removing the bottom tubesheet, the secondary inlet nozzle had to be cut with the modified band saw (Figure 5). Therefore the secondary inlet nozzle was cut one inch from the vessel to reduce the length of the band saw cut. Both openings were covered with a $\frac{1}{2}$ inch thick plexiglass plate taped in place. This allowed visual access without losing the nitrogen atmosphere. 


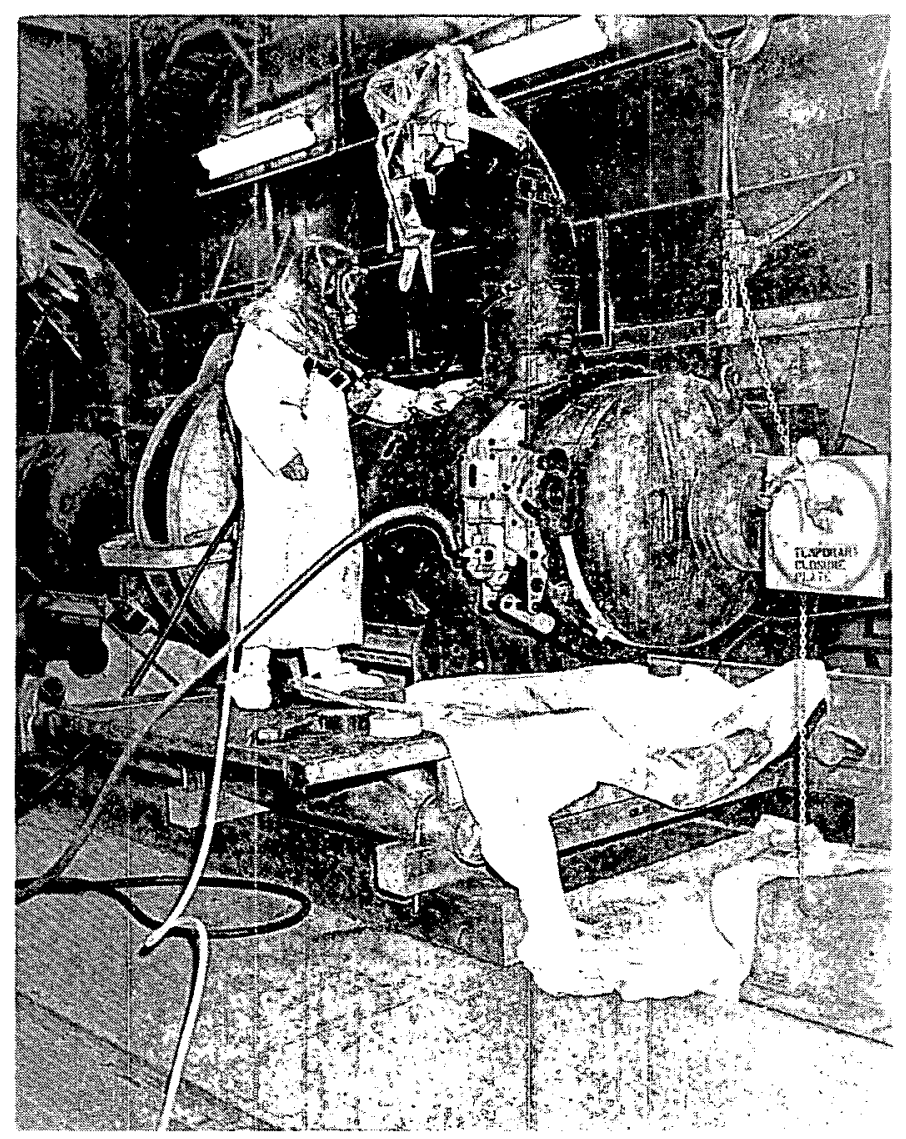

Fig. 3 Making final cut to remove top head.

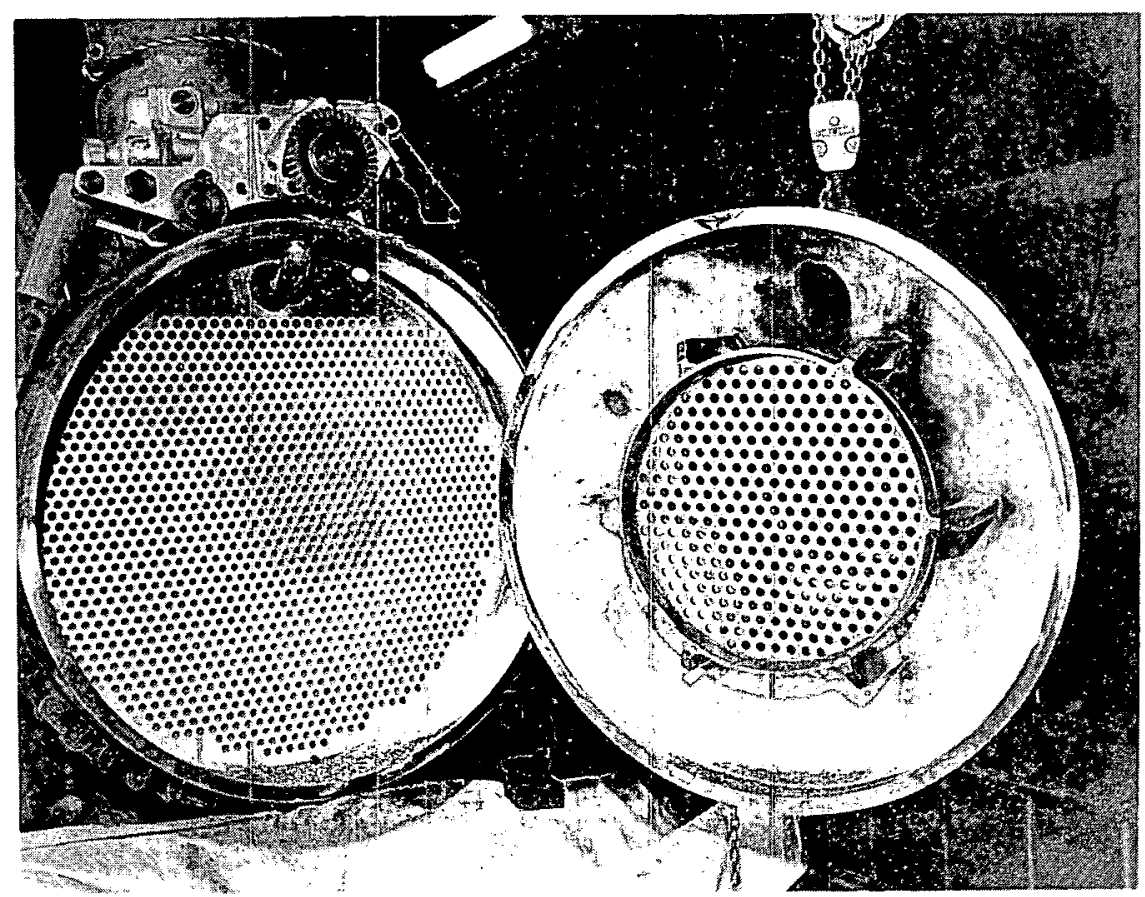

Fig. 4 Internal surfaces immediately after top head removal. 


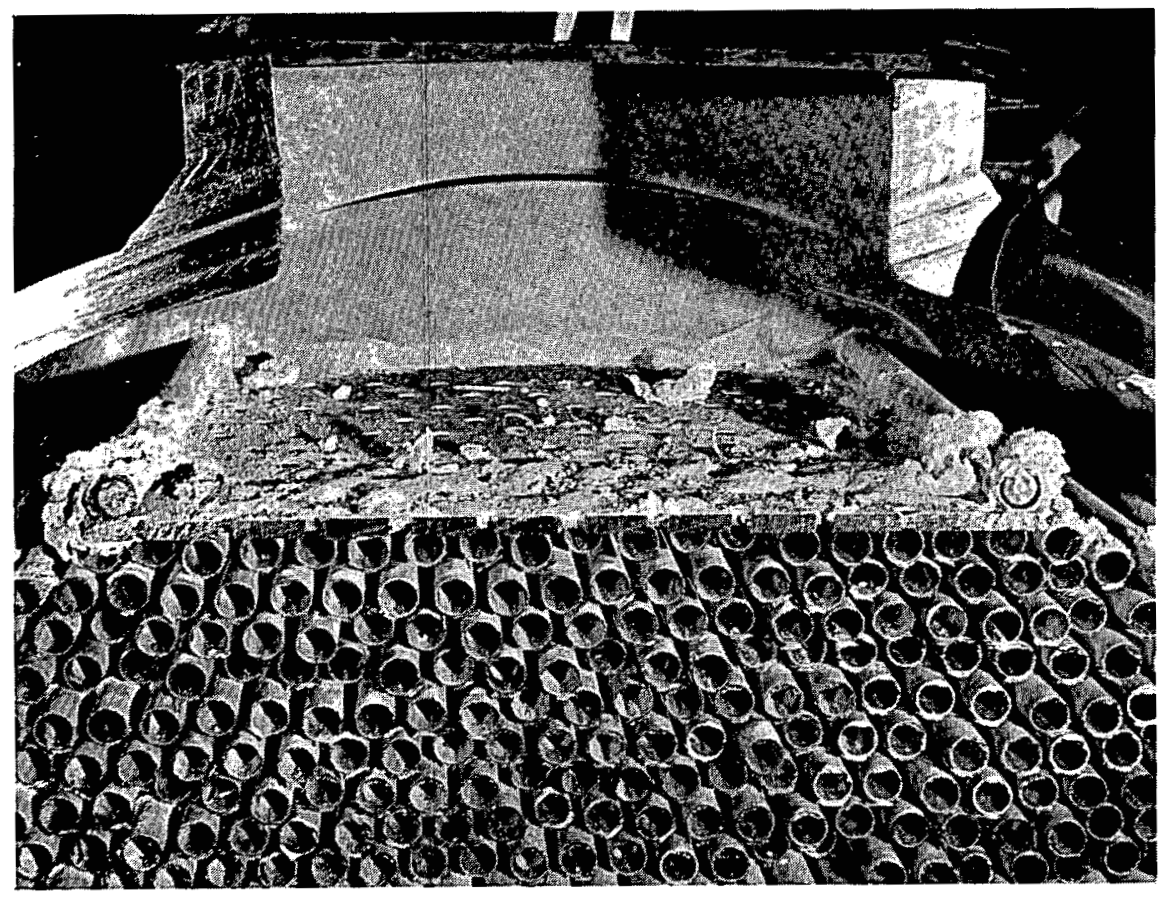

Fig. 5 Required cut through the secondary nozzle to remove the bottom tubesheet.

Removal of the tubesheets required cutting through the shell around the periphery of the vessel on the secondary side of the tubesheet and then cutting through all tubes. Match marks were placed on the tubesheet and vessel to maintain positive orientation after removal. The "Fein" pipe saw was used to cut through the vessel wall. The cut through the vessel wall was made in two passes around the vessel. The first pass was a $3 / 4$ inch deep cut with the aid of a cutting fluid. All traces of the cutting fluid were removed with acetone. The final cut was made without using a cutting fluid. A cable was put around the tubesheet and hooked to an overhead crane for support during cutting. A modified band saw (Figure 6 ) was used to saw through the tubes. The band saw blade penetrated down through the cut in the vessel wall made by the "Fein" pipe saw while cutting through the tubes. The tubesheet was moved away from the vessel and photographed as soon as the tubes were cut. The vessel opening was covered with plastic to preserve the nitrogen atmosphere inside the vessel.

A seven inch thick deposit of sodium was found on the secondary side of the bottom tubesheet. Due to the sodium deposit, it was necessary to make the cut to remove the bottom tubesheet eight inches above the back face of the tubesheet. The cut passed through the bottom side (Figure 7) of the secondary inlet nozzle. The "Fein" pipe saw was used to cut through the vessel wall around the periphery of the vessel but could not be used to cut through the secondary inlet nozzle section. The modified band saw was used to cut through this section. The tubes were then cut off by penetrating the modified band 


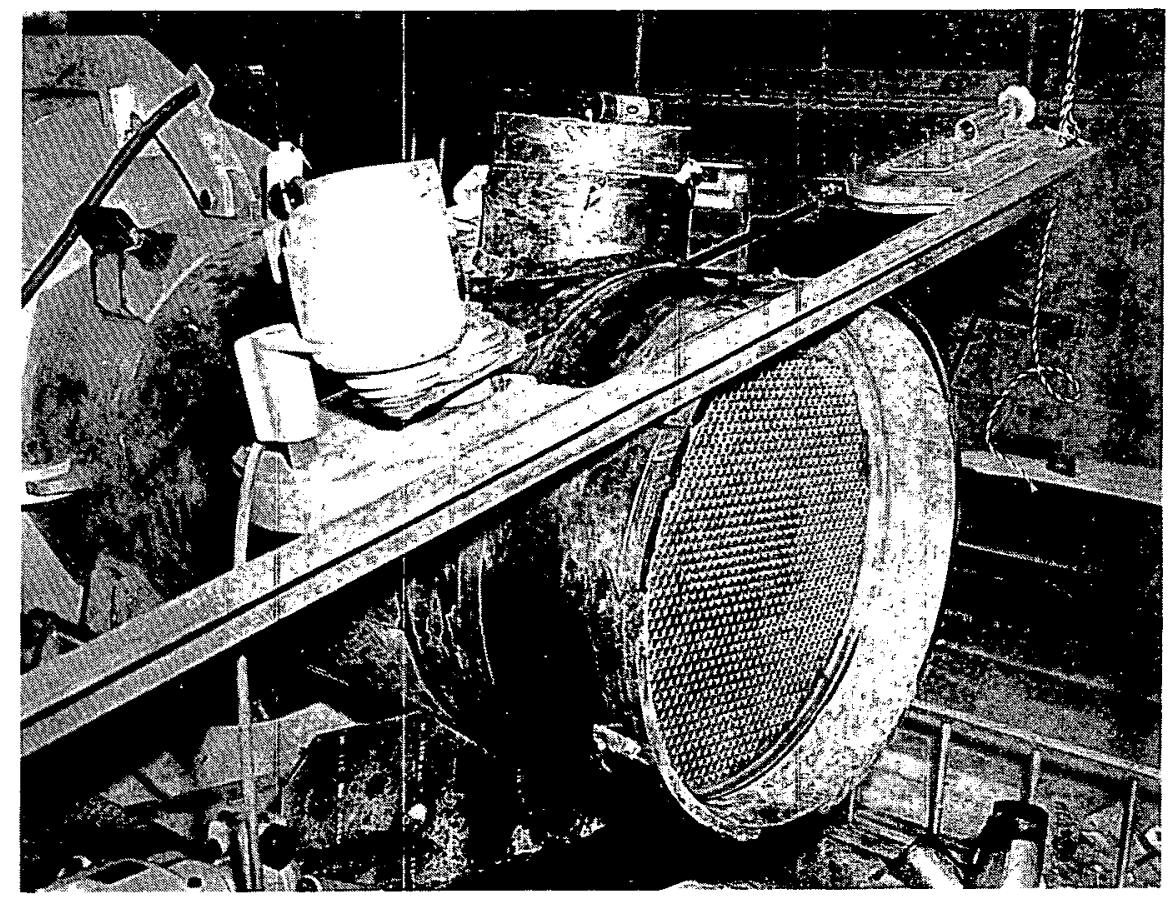

Fig. 6 Modified band saw cutting tubes.

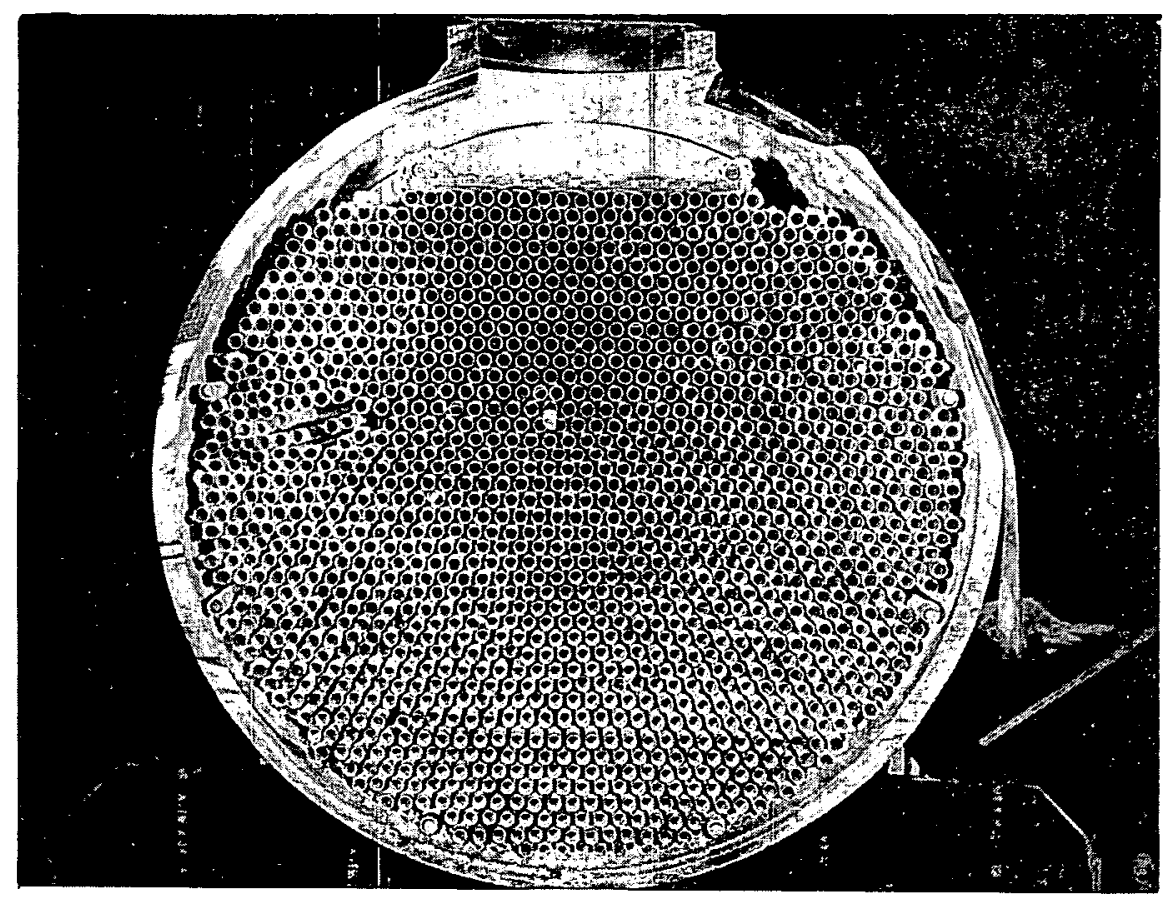

Fig. 7 Removing the bottom tubesheet with the "Fein" pipe saw. 
saw down through the slot in the vessel wall made by the "Fein" pipe saw and through the tubes.

A cable sling was put around the outside diameter of the tubesheet and hooked to an overhead crane to support the tubesheet during the cutting operations. The saw cut slot around the vessel was covered with tape to preserve the nitrogen atmosphere during the cutting of the tubes. The exposed end of the vessel was covered with plastic to maintain the nitrogen atmosphere immediately after tubesheet removal.

The bottom tubesheet was photographed (Figure 8) and then placed in a $4 \mathrm{ft}$. $x 4$ ft. $x 18$ inch stainless steel tank partially filled with 100 gallons of Dowanol DB. The tubesheet and sodium deposit were completely submerged in the Dowanol to react the sodium. The reaction rate was rapid the first three days. A circulation pump and methyl alcohol were added after three days to keep the reaction going. Fresh Dowanol and alcohol were added regularly and circulated with the pump. Holes were manually drilled in the sodium with a specially fabricated hand drill tool to remove sodium and to increase the surface area reacting with the Dowanol and alcohol. Reaction of approximately 130 pounds of sodium from the tubesheet took four weeks. No water was used to react the sodium.

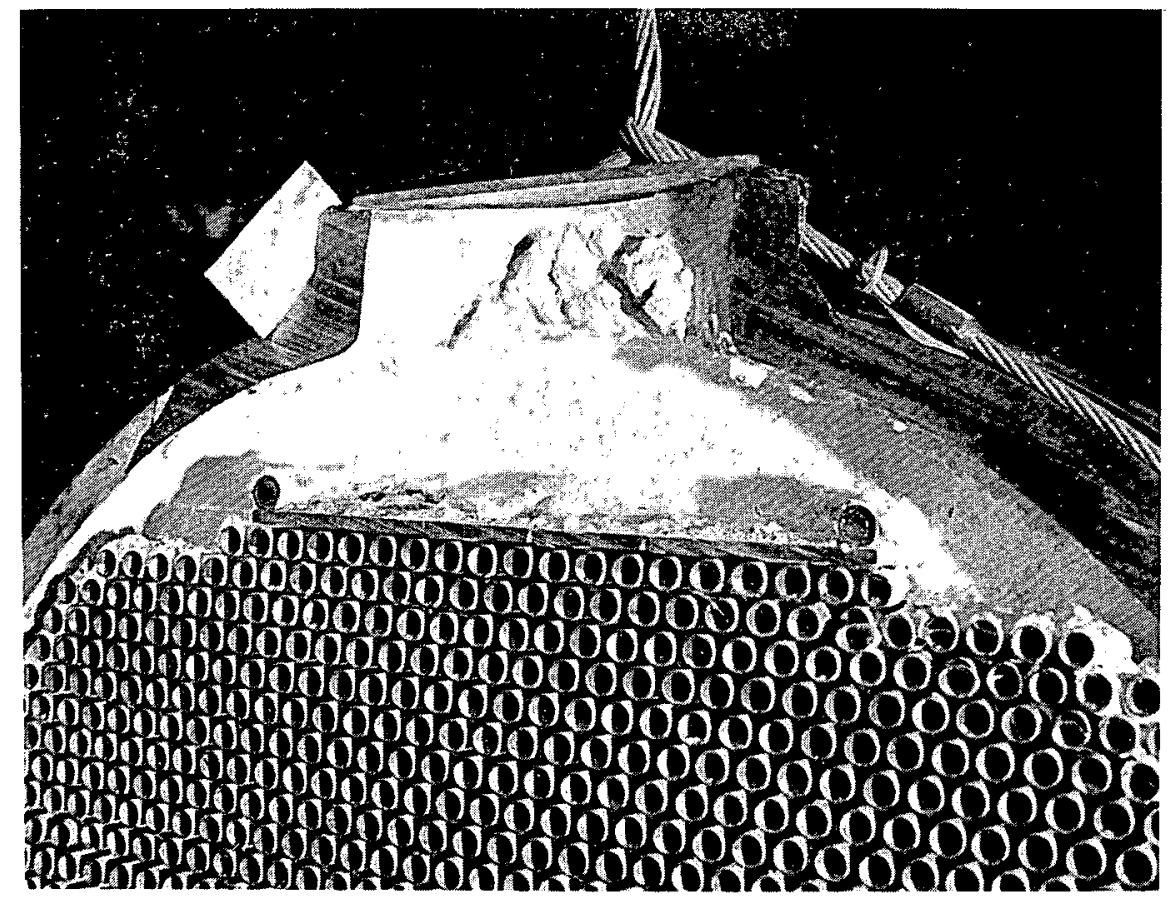

Fig. 8 Bottom tubesheet showing sodium deposit on secondary side. 
After both tubesheets were removed, the tubes were free to be pulled through the baffles (Figure 9) and removed from the vessel. Before removing the tubes each tube was numbered on the top end for identification. Original orientation of each tube was also preserved by notching each tube at the top end on the side facing the secondary nozzles. The tubes were then placed in a wooden storage rack.

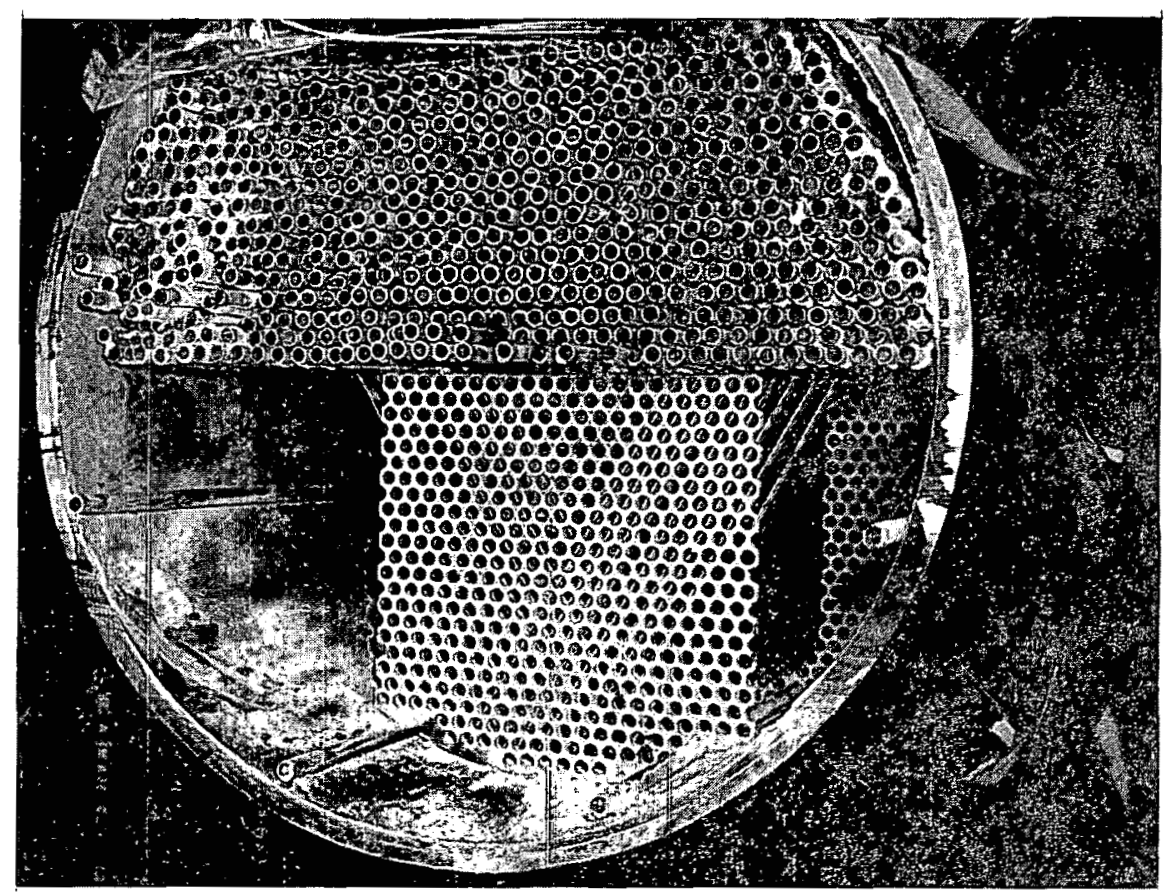

Fig. 9 Secondary side of vessel with a portion of the tubes removed

The techniques used to disassemble and examine the components of this vessel were necessary to fulfill one of the project objectives, to disassemble the unit without destroying any evidence of operational damage. This objective was achieved. The nitrogen atmosphere was relatively easy to maintain and from all indications appeared to be effective in isolating the internal components from the surrounding atmosphere. All surfaces exposed after a component of the vessel was removed were covered with plexiglass or plastic as soon as documentary photographs and visual examination were completed. The reacting of the approximately 130 pounds of sodium from the secondary side of the bottom tubesheet was completed using only Dowanol and alcohol. The use of Dowanol and alcohol resulted in a slow reaction which did not cause any damage to the tubes or tubesheet. This appears to be a relatively safe way to dispose of large amounts of sodium where the component is to be examined after the reaction. 
The techniques developed and experience documented here is applicable to the disassembly of other large sodium contaminated components.

\section{VISUAL OBSERVATIONS}

Visual observations of the unit before starting the disassembly work did not reveal any operational damage. All components removed from the vessel were visually inspected and no damage was detected. Visual inspection through the tubes showed some tubes with large deposits of sodium compounds internally. These deposits did not plug any of the tubes and were only localized deposits.

Visual inspection (Figure 10) of the tube-to-tubesheet crevices of the top tubesheet disclosed approximately $30 \%$ of the tubes with sodium compound deposits. Three samples each consisting of a single tube and a piece of the surrounding tubesheet were removed from the top tubesheet. These samples were mounted in a lathe and the section of tubesheet turned down to a 0.005 inch thick veneer surrounding the tube. The tube-to-tubesheet crevice of these three samples were then visually examined for the presence of sodium. The sodium had penetrated the crevice to the second groove in the tubesheet in all three samples. The sodium had penetrated to the back side of the tube-to-tubesheet weld in one sample. Sodium was also detected bleeding from the tubeto-tubesheet crevice of approximately $90 \%$ of the metallurgical samples taken from both tubesheets.

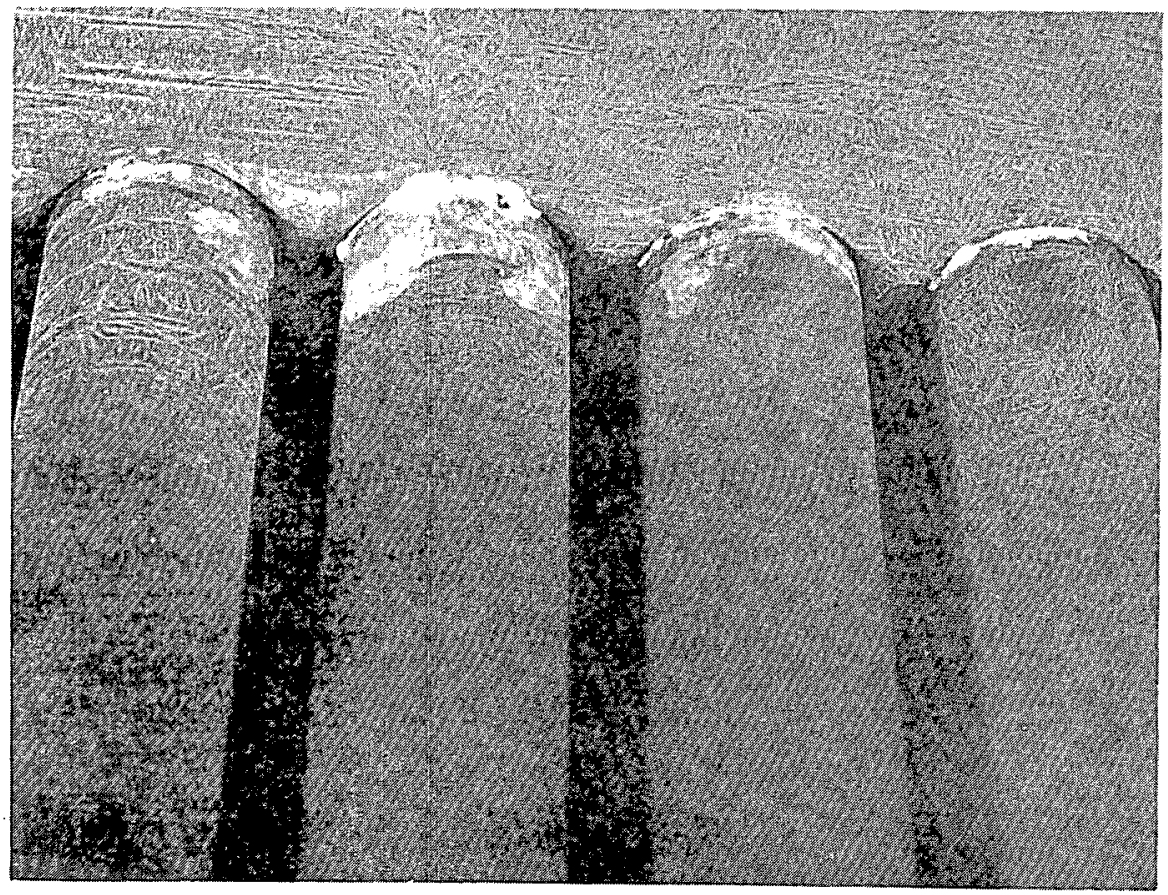

Fig. 10 Sodium deposits at tube-to-tubesheet crevice. 
No operational damage was visually detected on the vessel or any of the components removed from the vessel.

IV. NON-DESTRUCTIVE TESTING AND RESULTS

1. Radiation Surveys

Radiation surveys were made at the storage area prior to moving the unit to the disassembly area. A maximum radiation field of $0.5 \mathrm{mr} / \mathrm{hour}$ was detected at the extermal surface of the vessel expansion joint. This being the area of minimum wall thickness would account for the highest reading in this area. After disassembly, it was found that all of the contamination was restricted to the primary side of the vessel. Therefore the $0.5 \mathrm{mr} / \mathrm{hr}$. was from the contamination on the inside surface of the tubes.

During the helium leak check to select the IHX for disassembly, gas from both the primary and secondary sides of both vessels was filtered and checked for contamination. No contamination was detected on any of the gas filters.

Radioactive contamination smears of the intermal surface of the primary top head taken immediately after removal gave a count of 130 disintegrations/minute beta-gamma. An approximate conversion of this contamination count is $0.01 \mathrm{mr} / \mathrm{hr}$.

Gamma spectrometer identification of the principal radioactive isotopes showed them to be approximately $58 \% \mathrm{Co}^{60}$ and $42 \% \mathrm{Cs}^{137}$. Anti-contamination clothing such as coveralls, shoe covers and rubber gloves were required during some phases of work because of the contamination problem. No respiratory protection was required unless some operation was performed that could cause the contamination to become airborme, such as grinding since the contamination containing conpounds adhered to the vessel.

Radioactive contamination smears taken on the internal surfaces of the secondary side revealed no contamination on the secondary side of the IHX.

\section{Non-Destructive Tests}

The tube-to-tubesheet welds of both tubesheets were checked with a fluorescent dye for flaws or cracks. No cracks or flaws were detected by this method. Although one indication of a crack was found on the top tubesheet, further metallurgical investigation revealed no cracks or flaws. Dye penetrant examination of the tubesheet-to-vessel welds of both tubesheets did not detect any cracks or flaws.

Radiography of the tubesheet-to-vessel welds indicated minor amounts of porosity and lack of fusion. None of the five indica- 
tions were greater than 0.080 inch in length.

All tube openings in the top tubesheet were plugged with rubber stoppers to helium leak check the tubes in the top tubesheet. The nitrogen purge on the secondary side was reduced to one psi and then pressurized with helium to eight psi. The tube-to-tubesheet welds on the face of the top tubesheet were checked for leaks by placing the detector probe approximately $\frac{1}{4}$ inch from the weld and moving around the tube welds. This procedure was used on all the tube-to-tubesheet welds on the top tubesheet. No leaks were detected in any of the welds. To leak check the tubes one stopper was removed at a time and the helium leak detector probe inserted $\frac{1}{2}$ inch into the tube. Nitrogen was purged into the bottom head of the primary side with a flow of $15 \mathrm{cfh}$. This nitrogen purge through the one open tube would carry any helium leaking from the secondary side with it. The detector probe was left in the tube being checked for twenty seconds. A complete change of nitrogen gas in the tube occurred every ten seconds with a flow of $15 \mathrm{cfh}$. Therefore the detector should have picked up any indication in twenty seconds or less. After the probe was in the open tube twenty seconds it was removed and the rubber stopper replaced. This procedure was continued until each tube was leak checked. Three tubes gave positive indication of a leak. By inserting the detector probe to different locations down the tube and recording the maximum detector reading for thirty seconds all three (3) leaks were found to be located approximately 1 to $1 \frac{1}{4}$ inches from the tubesheet face. The three leaking tubes were: (Figure II)

$\begin{array}{ll}\text { Row \#18 } & \text { Tube \#33 } \\ \text { Row \#19 } & \text { Tube \#33 } \\ \text { Row \#33 } & \text { Tube \#17 }\end{array}$

The following system was used to document the identity and orientation of tube location within the IHX of leaking tubes and tubes used for metallographic examination: facing the top tubesheet, with the vent line opening at the top, each horizontal row of tubes is numbered consecutively starting with the top row as row one, the second row as row two, etc.. Each tube in a row is also numbered, starting at the left end of each row with tube number one numering consecutively to the right. To maintain orientation, each tube was permanently marked on the outside surface of the tube closest to the secondary nozzles. After all the tubes were leak checked, the tubesheet face was washed with Dowanol DB and the tube-to-tubesheet welds were checked again for leaks. No leaks were found in the welds.

In consultation with IMEC, it was agreed that the bottom tubesheet should be helium leak checked separately after the potential sodium plugging had been removed. This test had to wait until the bottom tubesheet was removed and the sodium reacted away. A plate was mounted over the exposed secondary side of the bottom 


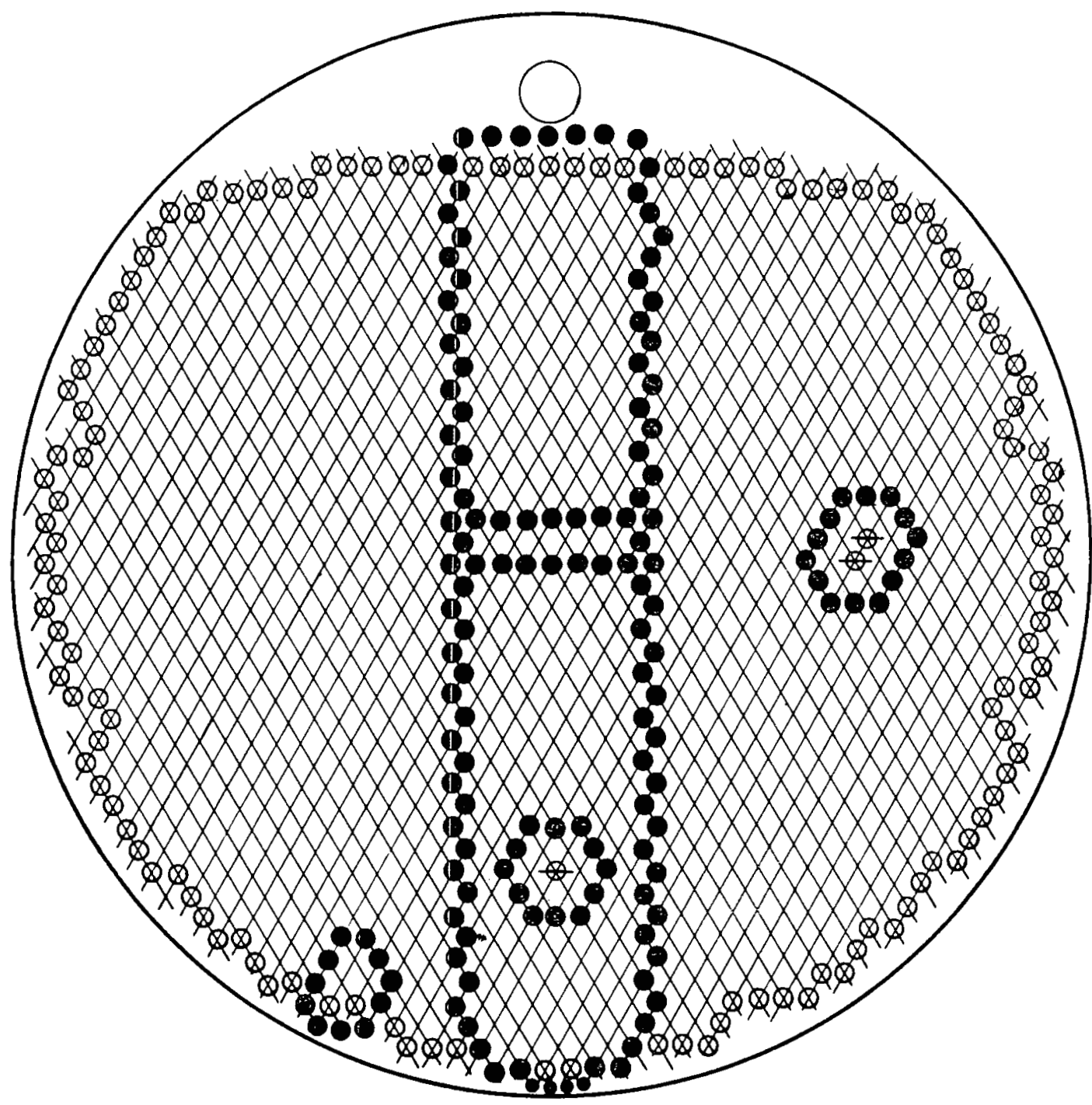

Fig. Il Location of samples removed from top tubesheet.

Leaking Tubes
Holes Drilled to Remove Samples

tubesheet to allow helium leak checking of the tubes attached to the tubesheet. The cut tubes extended approximately six inches above the tubesheet. All 1395 tubes were plugged with solid rubber stoppers. A 1/8 inch thick circular plate was then seal welded to the $8 \frac{1}{4}$ inch long section of vessel removed with the bottom tubesheet. The volume enclosed by the section of vessel wall, the circular plate, and the back side of the tubesheet was then pressurized to three psi with helium. The helium leak detector probe was then inserted approximately $\frac{1}{2}$ inch into the tube and left for twenty seconds. Each tube was checked in this manner. Six tubes showed indication of leaks. Additional stoppers were inserted from the tubesheet face into these six tubes to reduce the 
possibility of any helium leaking around the rubber stoppers. These six tubes were purged with air and sampled again for helium. Helium was still detected in all six tubes. The tubes suspected of leaking are listed below: (See Figure 12 for location)

$\begin{array}{ll}\text { Row } 1 & \text { Tube \#11 } \\ \text { Row } 1 & \text { Tube \#18 } \\ \text { Row } 2 & \text { Tube \#18 } \\ \text { Row } 3 & \text { Tube \#20 } \\ \text { Row } 4 & \text { Tube \#31 } \\ \text { Row } 8 & \text { Tube \#36 }\end{array}$

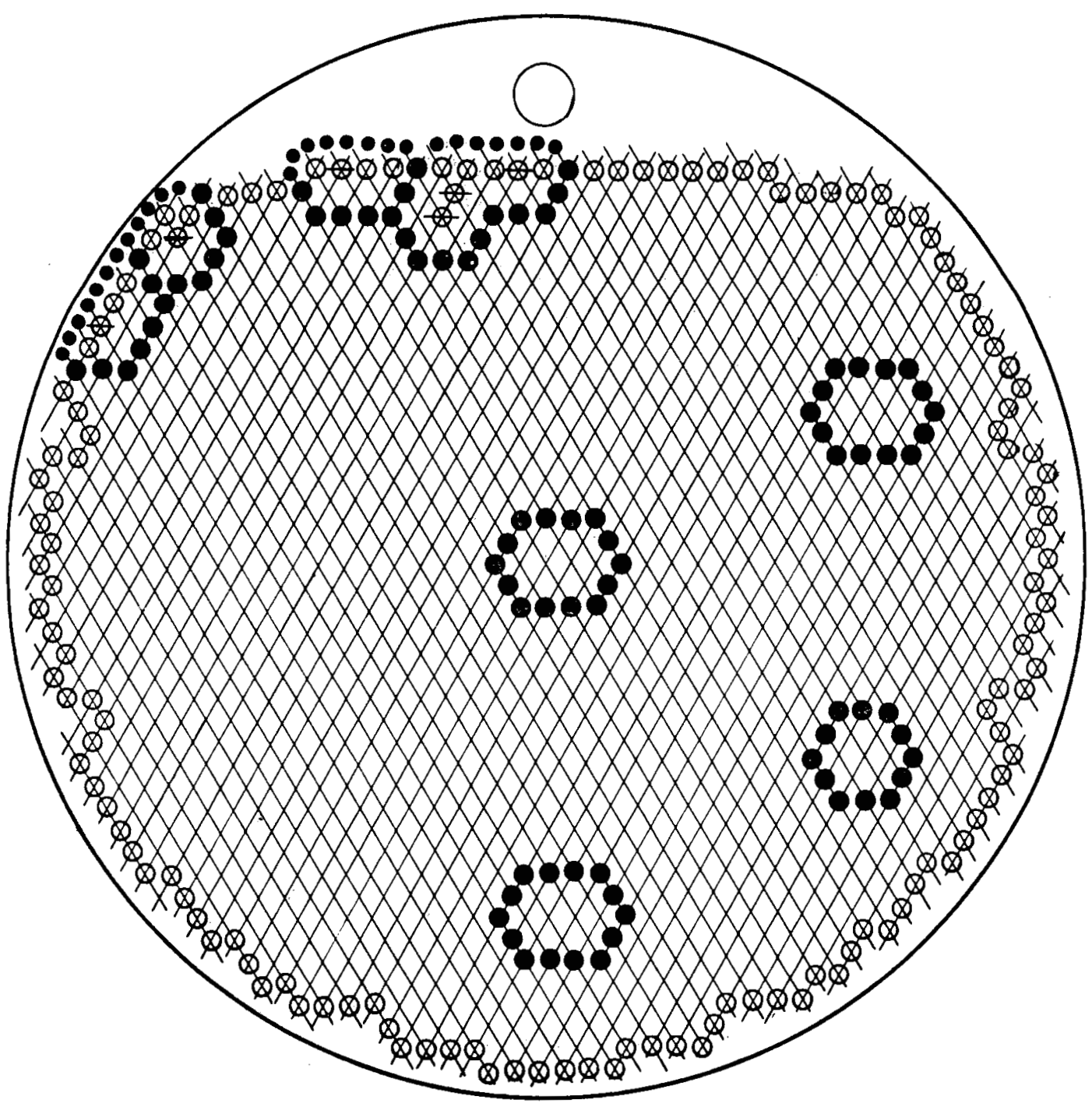

Fig. 12 Location of samples removed from bottom tubesheet. Suspected Leaking Tubes
Holes Drilled to Remove Samples 
No leaks or indications of leaks were found in any of these tubes when metallurgically examined. The inside surface of these tubes were also dye checked and no indications of leaks were found. All indications are that these six tubes did not leak but instead helium leaked around the mubber stoppers during the helium leak check.

\section{DESTRUCTIVE EXAMTNATION AND RESULTS}

1. Tube-to-Tubesheet Welds

A total of seventy one tube-to-tubesheet welds were examined from the top and bottom tubesheets. Forty one (Table I) were from the top tubesheet and thirty from the bottom tubesheet. See figures 11 and 12 for locations. Welds were examined at two places $180^{\circ}$ apart. Welds were examined for lack of fusion, cracking, porosity, sensitization and other weld defects.

TABLE I - Tubesheet Examinations

\begin{tabular}{lcc} 
& $\begin{array}{c}\text { Top } \\
\text { Tubesheet }\end{array}$ & $\begin{array}{c}\text { Bottom } \\
\text { Tubesheet }\end{array}$ \\
\cline { 2 - 3 } Tubes Examined & 20 & 27 \\
Tubes Showing Cracks & 5 & 0 \\
Ligaments Examined & 42 & 34 \\
Ligaments Having Cracks & 13 & 0 \\
Welds Examined & 41 & 30 \\
Welds Showing Defects & 1 & 0
\end{tabular}

Samples were removed from the tubesheets by drilling out the ligaments surrounding the samples. (Figure 13) These samples were split so the exposed edge contained longitudinal sections of two or three tubes and the tubesheet ligaments (Figure 14). Preparation of these extra large specimens for metallographic examination was accomplished by manually holding the specimens through the various polishing procedures. The specimens were then prepared for examination with a 10\% oxalic acid electrolytic etch. The samples were then examined on the metallograph at various magnifications up to 500X. Photomicrographs were taken of typical areas of the welds (Figures 15, 16 \& 17). Of all seventy one 


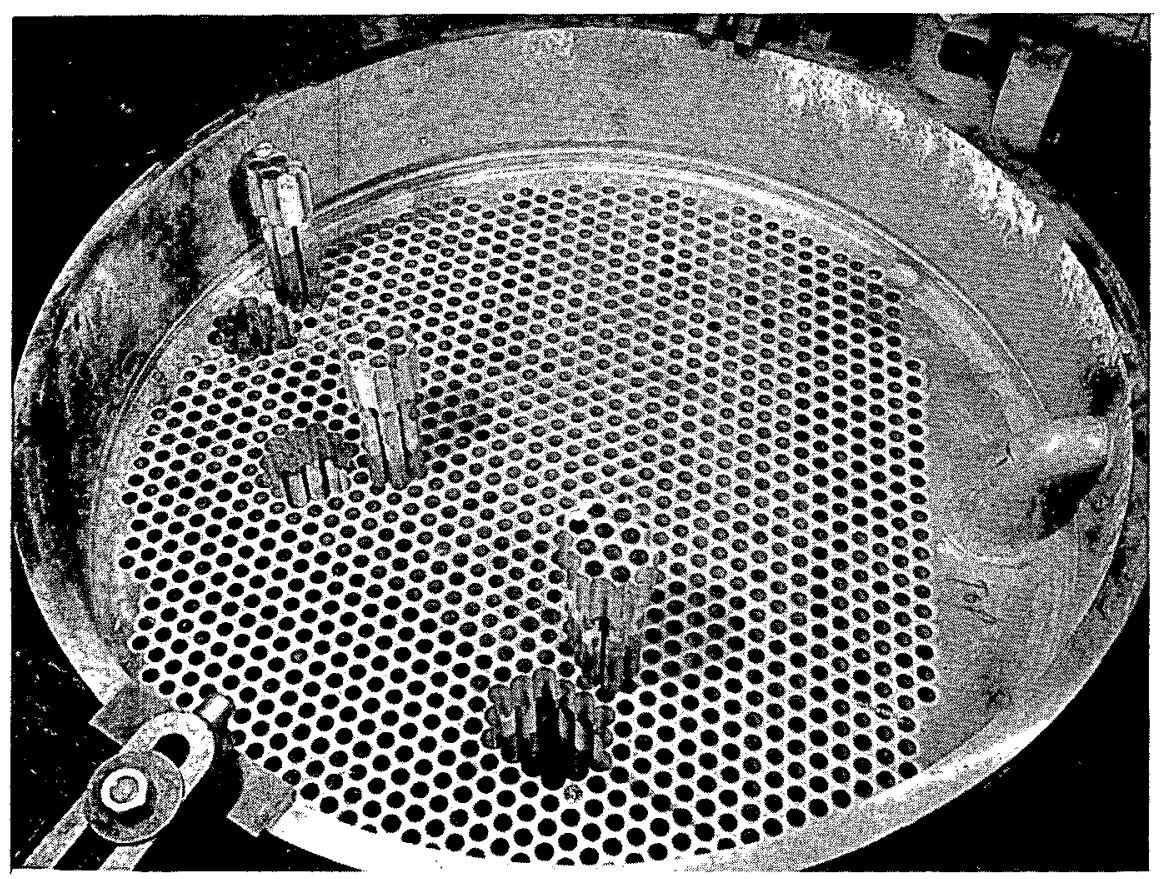

Fig. 13 Samples as they were removed from tubesheet.

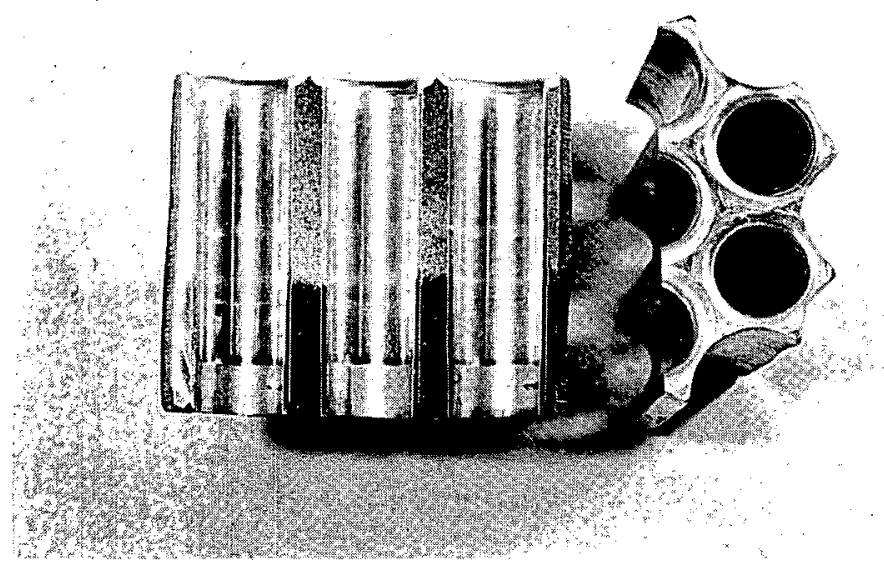

Fig. 14 Typical sample configuration. 


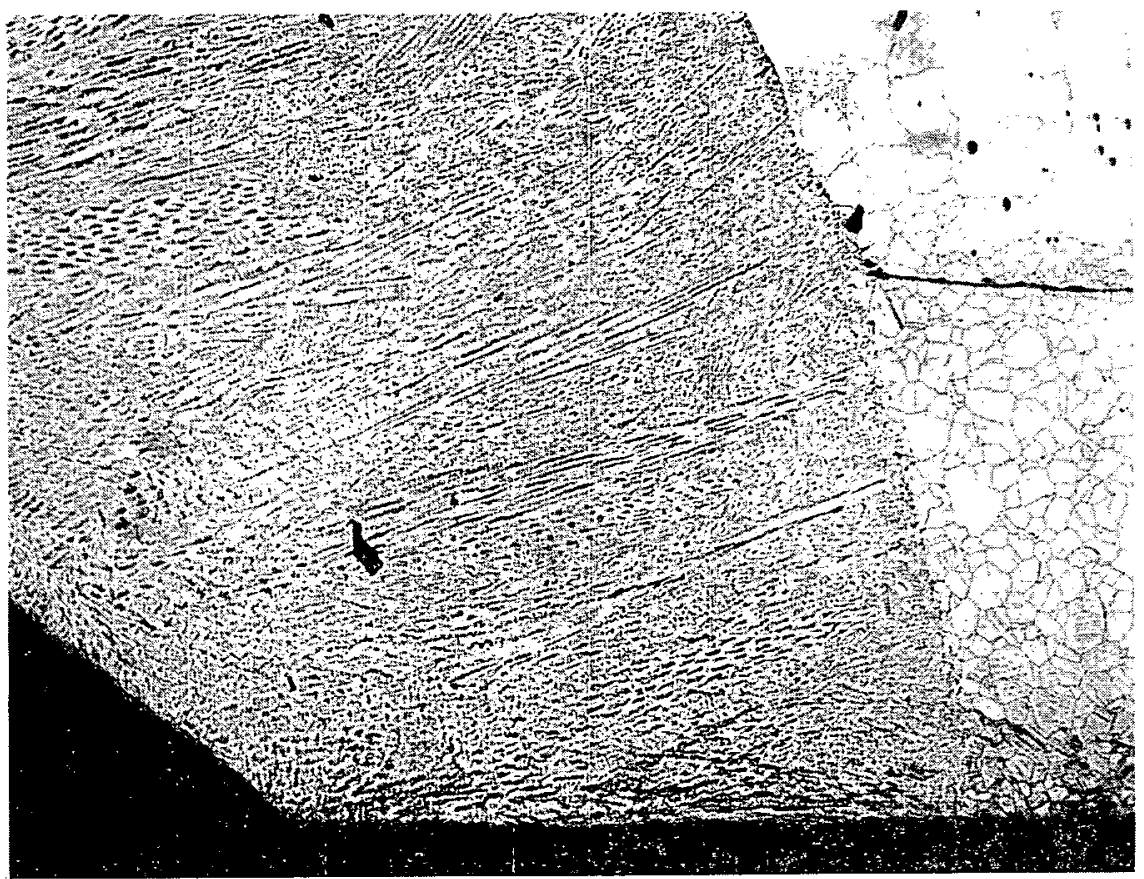

(A)

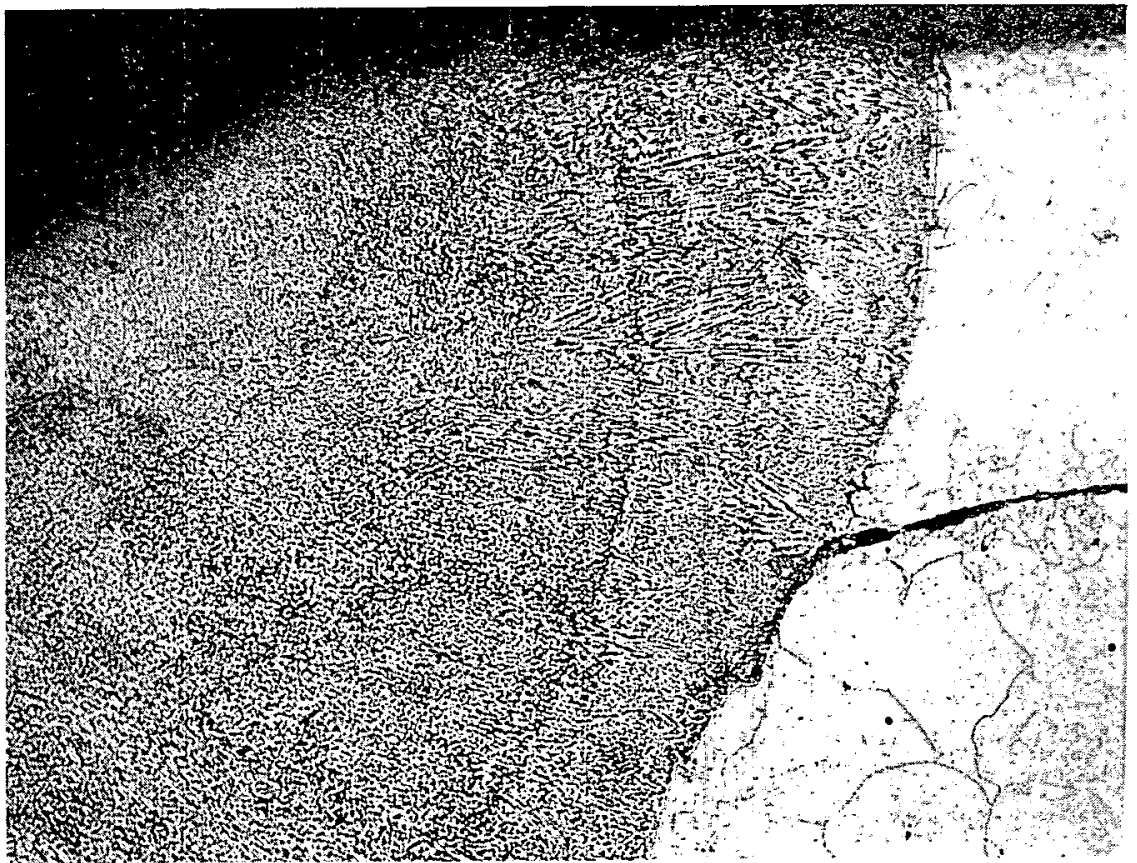

(B)

Fig. 15 Photomicrographs of typical tube-to-tubesheet welds examined from the top tubesheet.
A. Row 17 Tube 20 Mag. 60X
B. Row 20 Tube 32 Mag. $60 \mathrm{X}$ 

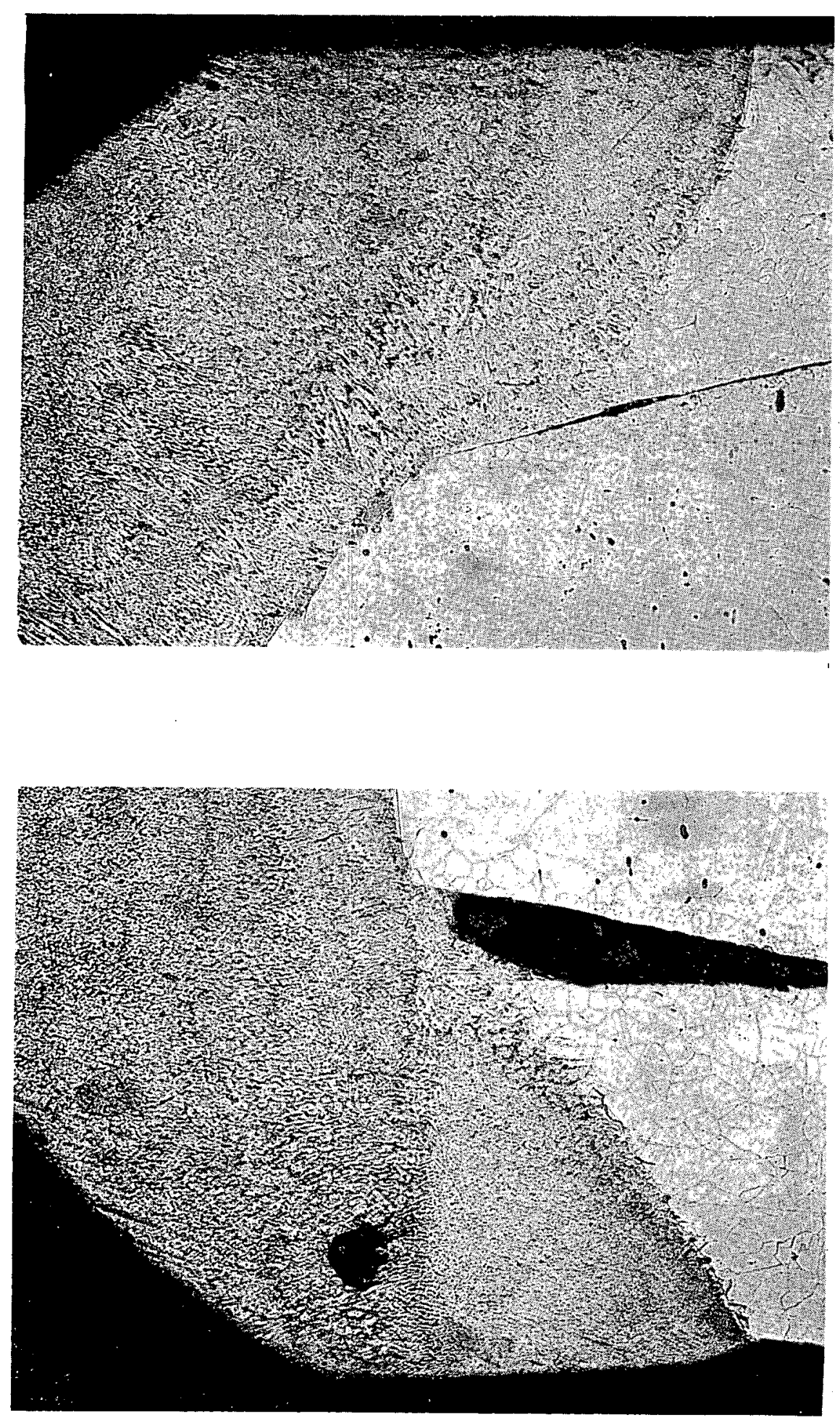

(B)

Fig. 16 Photomicrographs of typical short tube tube-totubesheet welds examined from the top tubesheet.
A \& B. Row 17 Tube 19 Mag. 60X 

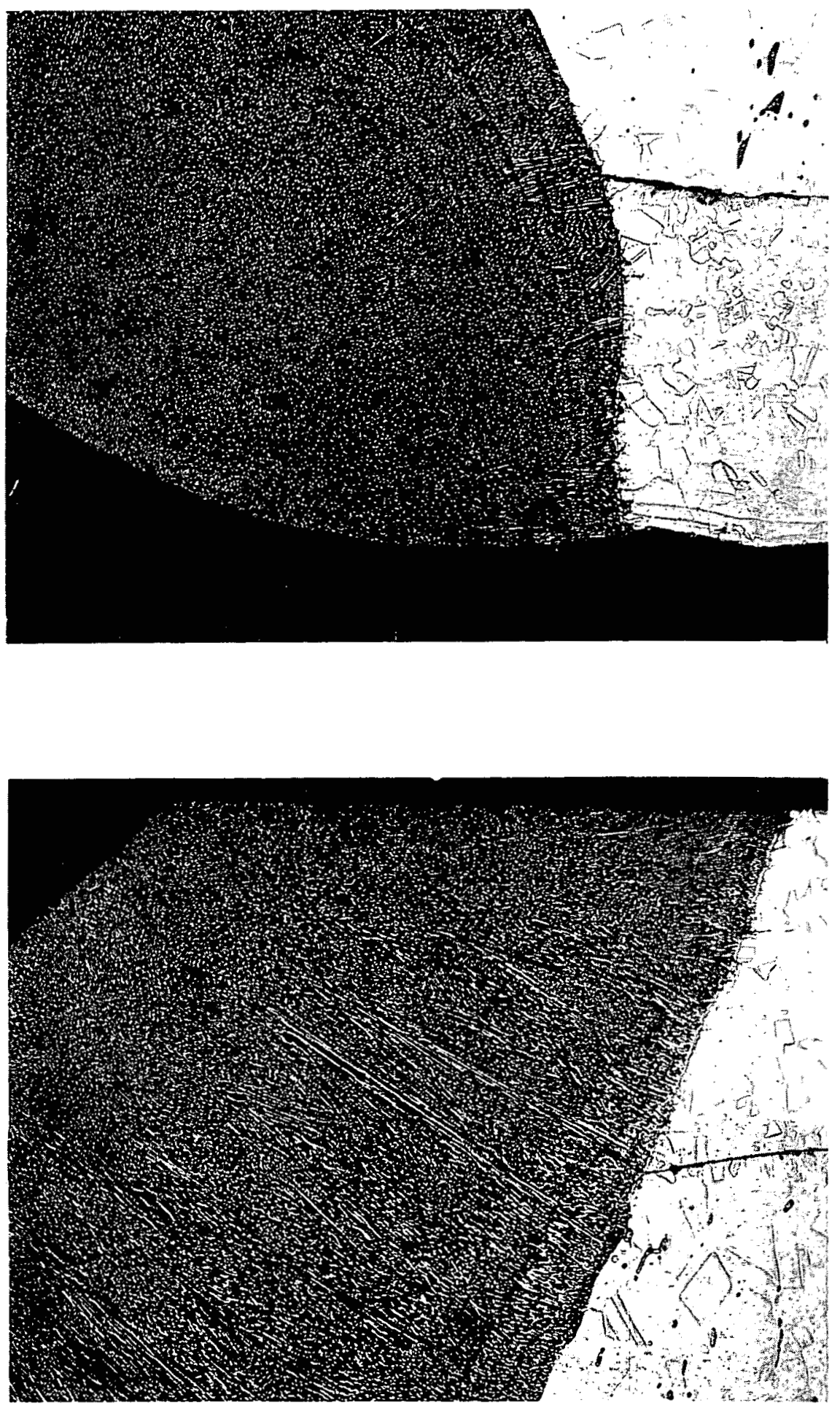

(B)

Fig. 17 Photomicrographs of typical tube-to-tubesheet welds examined from the bottom tubesheet.

A \& B. Row 28 Tube 7 Mag. 60X 
welds examined only one showed a lack of fusion and penetration. It was on one of the short tubes that had been installed in this IHX. This defect did not appear to affect the integrity of the weld since no cracking was found. The tube rolling was not effective (Figures 18 \& 19) in transfering the tube loading to the tubesheet in most samples examined. The welds functioned as a load bearing mechanism as well as a seal. Even under the se conditions none of the seventy one welds examined ( 142 weld sections) showed any cracks.

2. Tubes and Tubesheet

The tubes and tubesheet ligaments of the above samples were examined for defects and operational damage (Table I). Metallographic examinations of the three leaking tubes from the top tubesheet revealed micro cracks penetrating the walls of all three tubes (Figure 20). The cracks were transgranular and propogated from the tube outside diameter to the tube inside diameter. The cracks were in a plane parallel to the axis of the tubes. Two other cracked tubes were found in the top tubesheet. Both cracks penetrated approximately half way through the tubes from the outside diameter. No cracking was found in any of the tubes examined from the bottom tubesheet.

Transgranular micro-macro cracking (Figure 21) was found in thirteen of the forty two top tubesheet ligaments examined. This cracking was found in a plane parallel to the tubesheet face and about half way through the tubesheet. All cracks in the tubes except one were adjacent to cracks in the tubesheet. No cracking was found in any of the ligaments examined from the bottom tubesheet.

3. Tube-to-Tubesheet Crevice

Sodium was present in the tube-to-tubesheet crevice of all samples examined for this condition. In some samples examined sodium deposits were found the full length of the crevice while in others the sodium was found only near the tube-to-tubesheet weld. In some cases the sodium had penetrated the tube-to-tubesheet crevice to the back side of the weld but did not effect the integrity of the weld. Sodium was found in at least one groove and in most cases both of the grooves in the tubesheet in all specimens examined (Figure 22). The presence of sodium in the crevice did not appear to damage the tubes or the tubesheet, as no correlation was found between sodium deposits in the crevices and tube or tubesheet ligament cracks.

Due to the transgranular cracking pattern stress corrosion was suspected as the cause of the tube and tubesheet failures. Tests were then performed to check for the presence of chlorides, although this was not called for in the original examination plan. Chlorides were found in the tube-to-tubesheet crevice of both the top and bottom tubesheets. The presence of chlorides was determined by 
the following procedure: a tube and a surrounding piece of tubesheet was removed from the tubesheet by drilling out the ligaments between the tubes. The removed piece was mounted in a lathe and the surrounding tubesheet turned down to a thickness of approximately 0.005 inches. The thin veneer of tubesheet surrounding the tube was then slit longitudinally on one side with the lathe tool. All drilling and cutting was done without any cutting fluids of any kind. After slitting the tube it was immediately placed in a plastic bag and transported to the chemical analysis laboratory. The section of tubesheet was removed from the tube at the laboratory. Both pieces were handled in such a manner that the crevice surfaces did not come into contact with any substance or material which could contaminate them with chlorides. The colorimeteric method using mercuric thiocyanate was then used to determine the presence of chloride. A total of six samples (three samples from each tubesheet) were checked for the presence of chlorides. The sample number and its respective amount of chloride are listed below.

Top Tubesheet

Sample A

Sample B

Sample C

Bottom Tubesheet

Sample A

Sample B

Sample C
Chloride (micrograms/sample)

225

365

580

Chloride (micrograms/sample)

145

100

193

Due to the presence of chloride and the transgranular cracking pattern it was concluded that the cracking of the tubes and top tubesheet were caused by stress corrosion.

4. Tube Sections at Baffles

Metallurgical samples of sections of the tubes were removed from the areas where they penetrated the baffles. These samples were compared at a magnification of looX with a control sample of the particular tube from which the sample was removed. None of the forty samples examined exhibited any wear or corrosion damage. Although some of the tubes were polished bright where they penetrated the baffles, none of the tubes examined visually and metallurgically showed any signs of operational damage in the areas having contact with the baffles. 


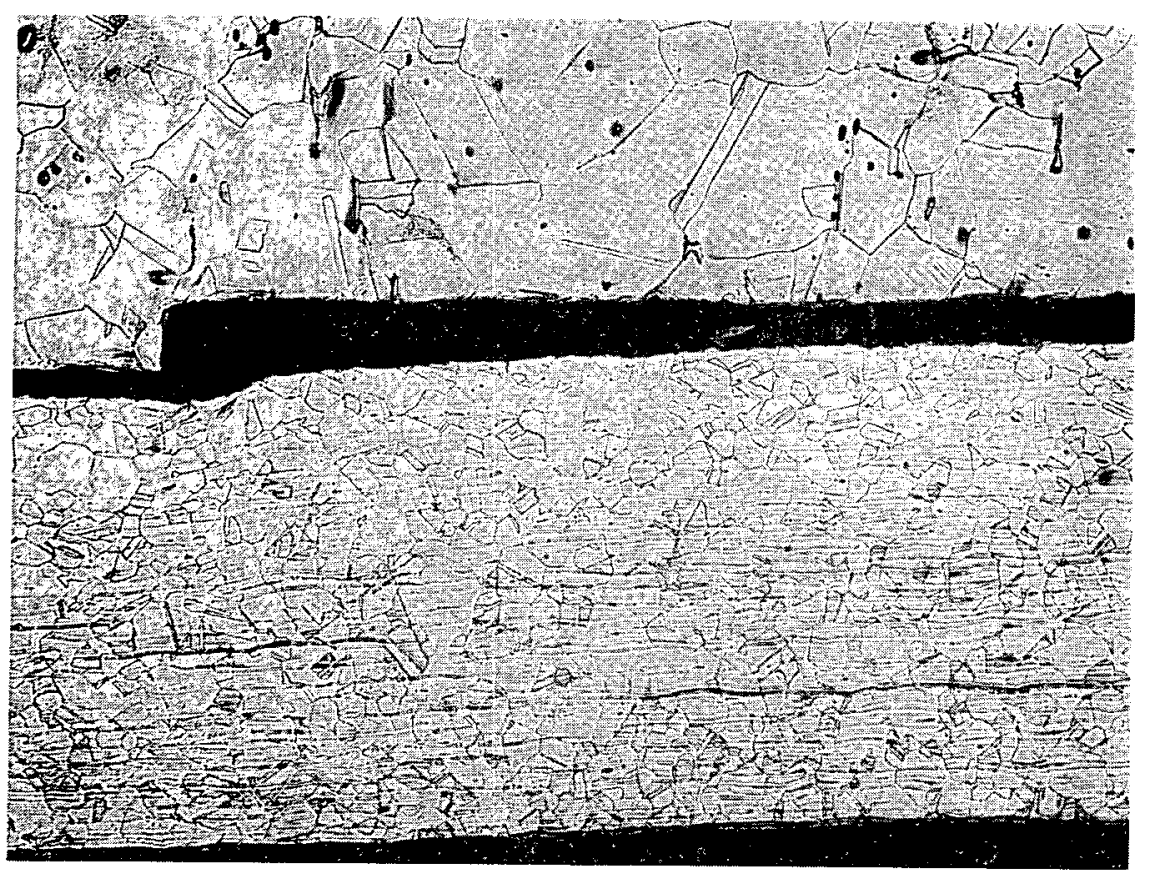

(A)

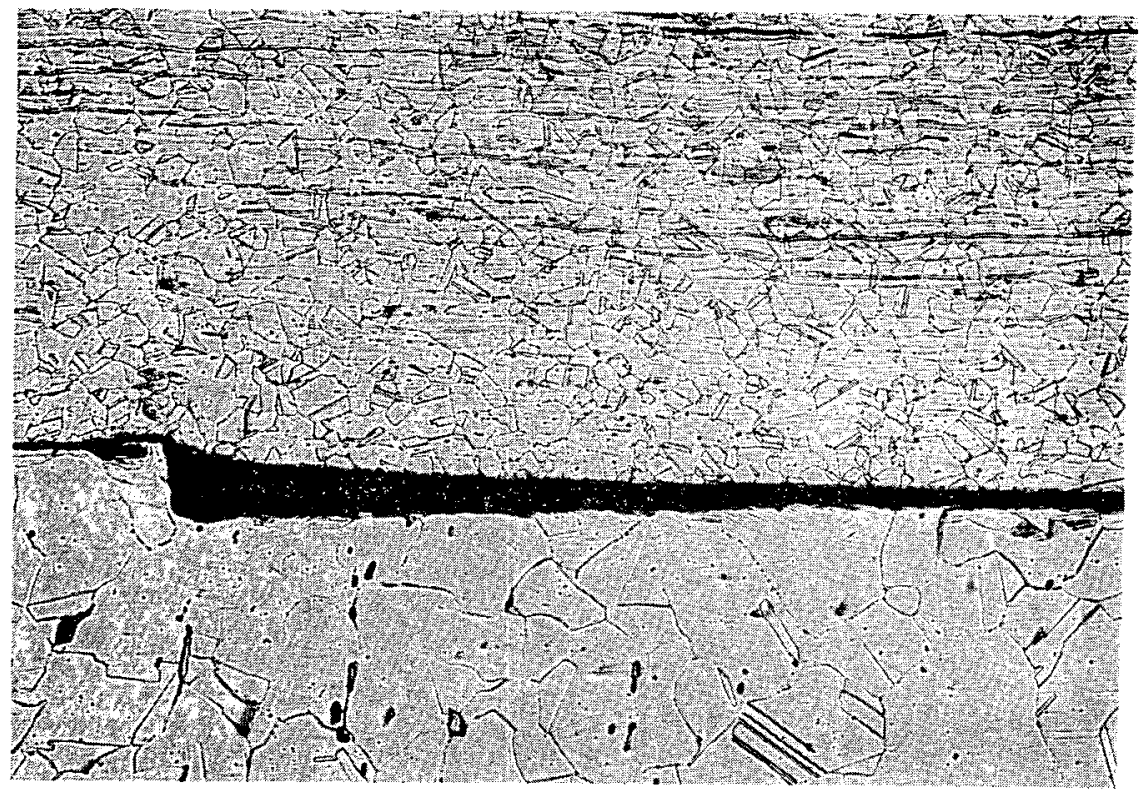

(B)

Fig. 18 Photomicrographs of effective tube rolling in the bottom tubesheet.

A \& B. Row 28 Tube 7 Mag. 60X 


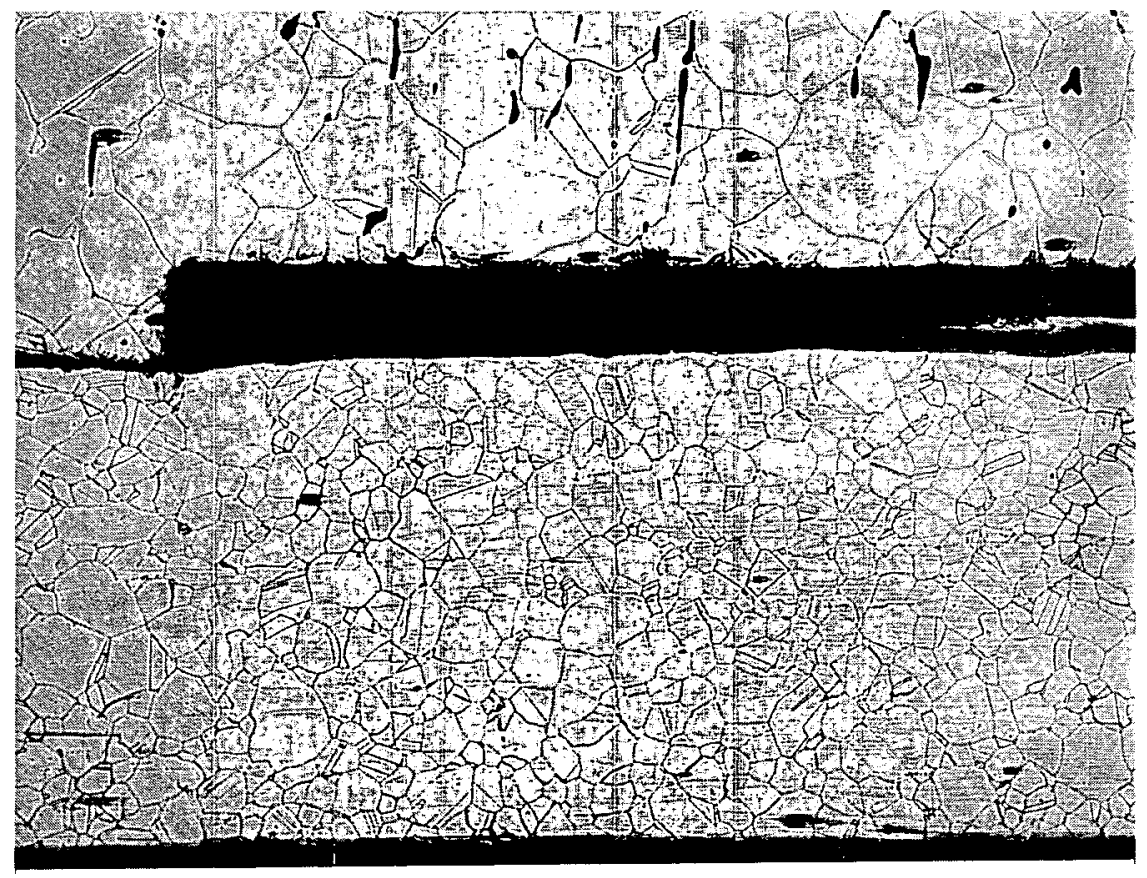

(A)

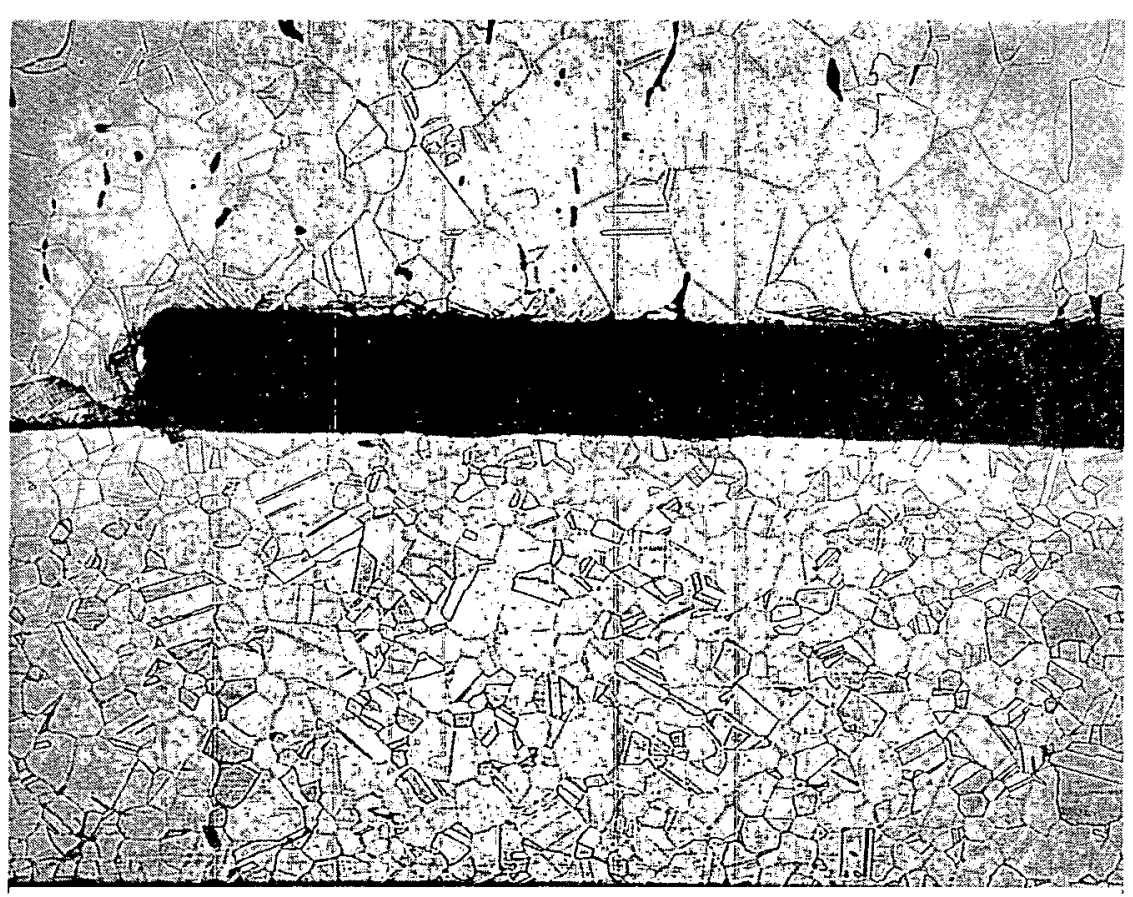

(B)

Fig. 19 Photomicrographs of ineffective tube rolling in the top tubesheet.
A \& B. Row 19 Tube 19 Mag. 60X 

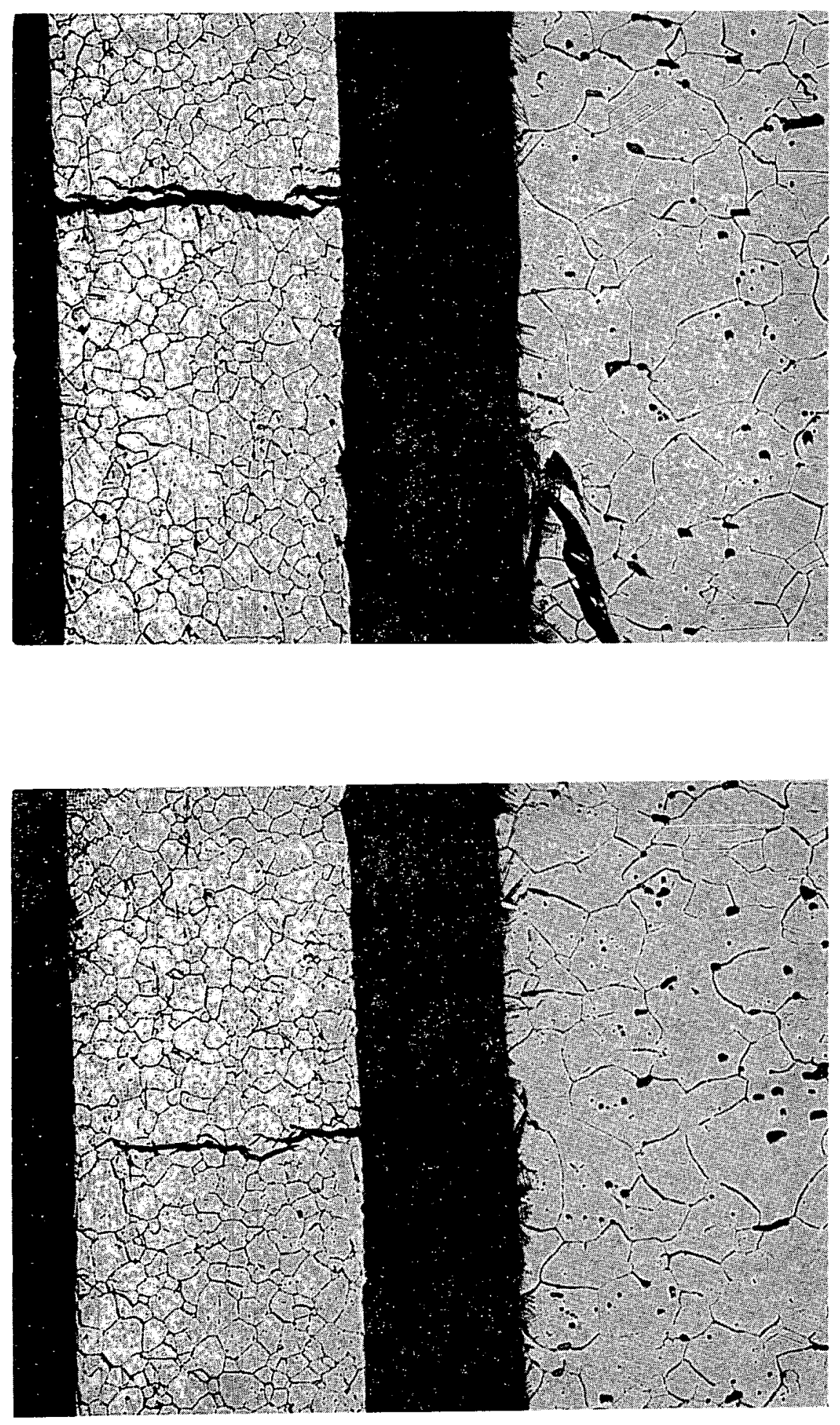

(B)

Fig. 20 Photomicrographs of cracked tube from top tubesheet.

A. Row 18 Tube 33 Mag. 60X

B. Row 19 Tube 33 Mag. 60X 

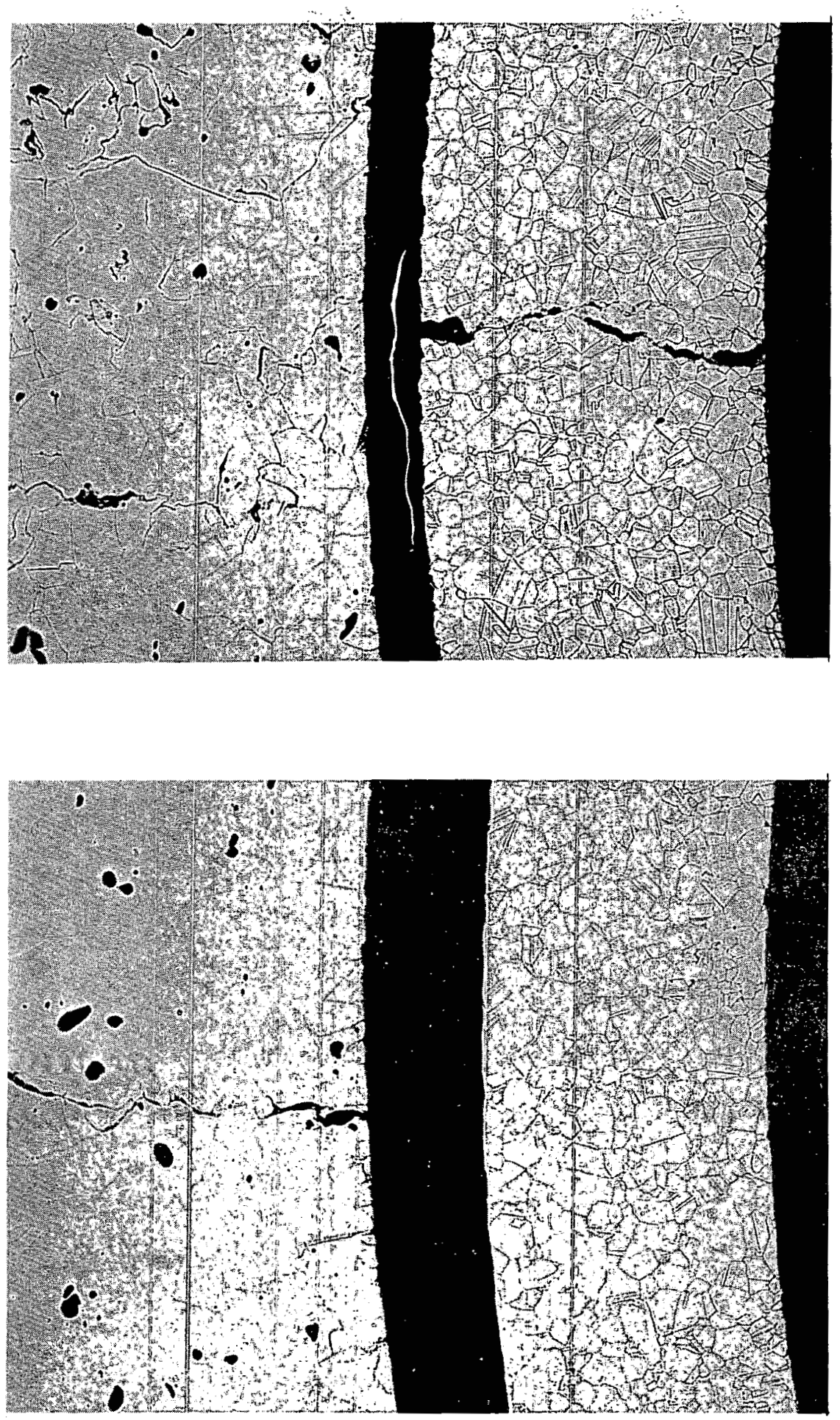

Fig. 21 Photomicrographs of cracking found in top tubesheet in area of row 33, tube 17. Mag. 60X 


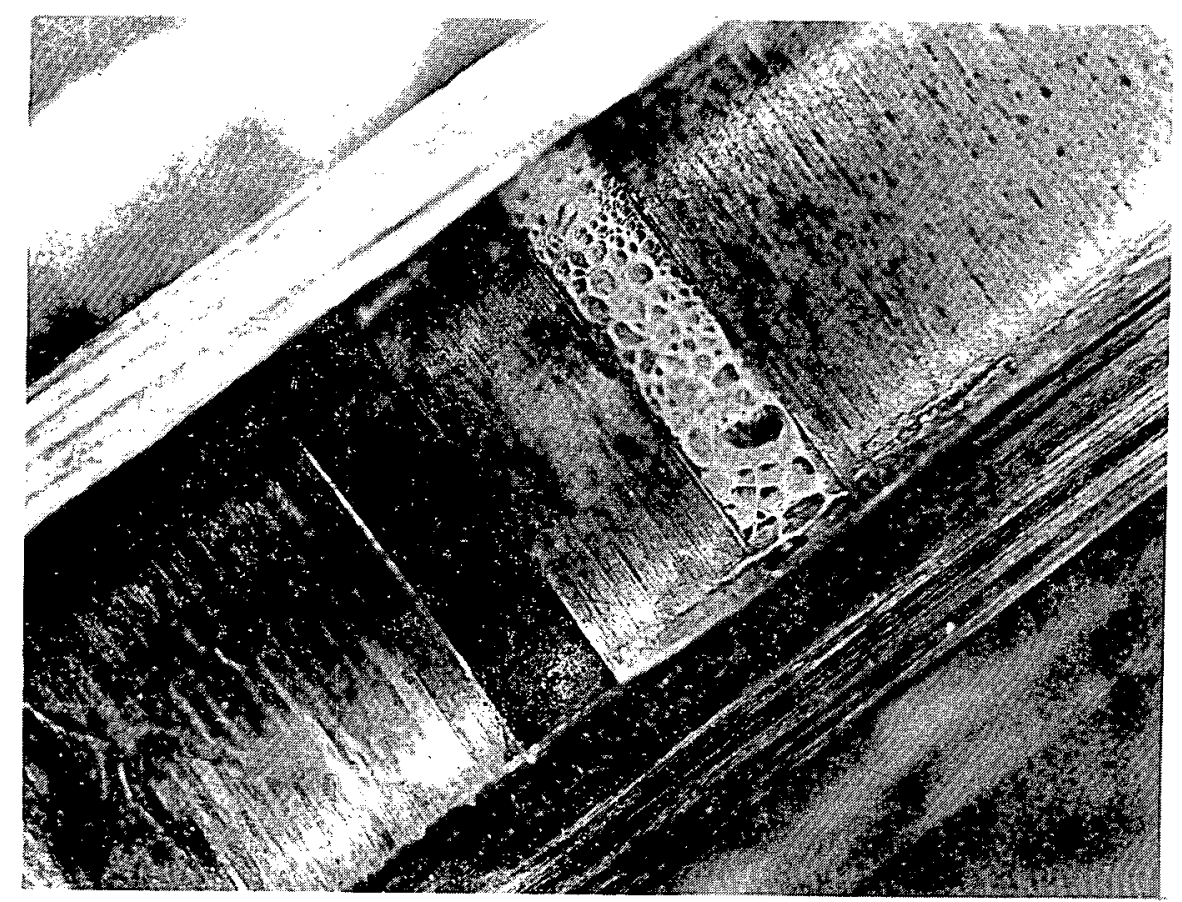

Fig. 22 Sodium in the tube-to-tubesheet crevice. 
APPENDIX A

RELIABILITY \& QUALITY ASSURANCE

INSPECTION REPORTS 
FORM INC $573(4-69)$ QA

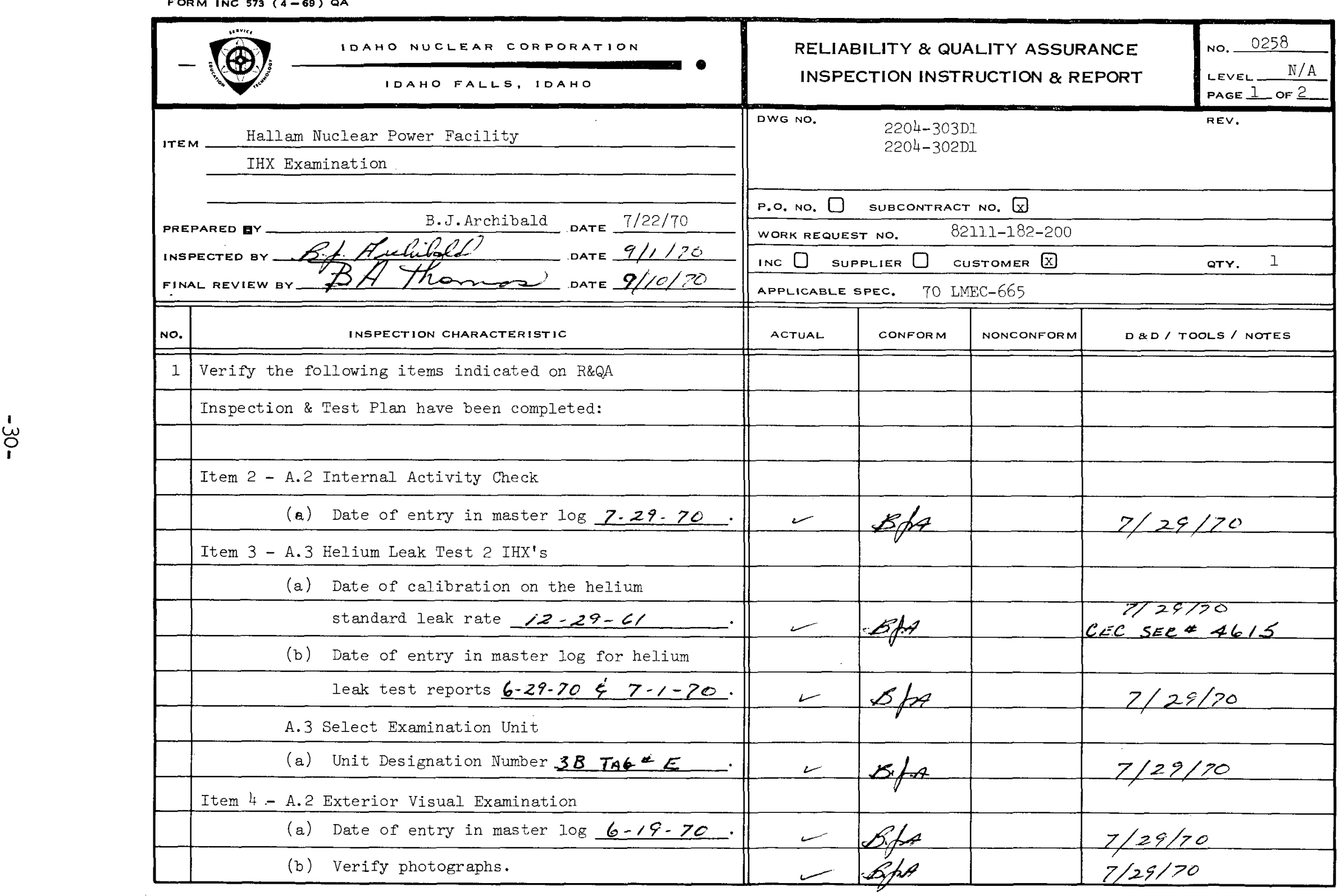


FORM INC 573-A (4-69) QA

\begin{tabular}{|c|c|c|c|c|c|c|}
\hline \multicolumn{2}{|r|}{-19. $\frac{\text { 10Aho nuclear corporation }}{\text { ioaho falls, idaho }}$} & \multicolumn{4}{|c|}{$\begin{array}{l}\text { RELIABILITY \& QUALITY ASSURANCE } \\
\text { INSPECTION INSTRUCTION \& REPORT } \\
\text { (CONTINUATION SHEET) }\end{array}$} & $\begin{array}{l}\text { NO. } \frac{0258}{\text { NeL N/A }} \\
\text { DAGEL } \frac{2}{-} \text { OF } \frac{2}{2}\end{array}$ \\
\hline м.. & INSPECTION CHARACTER ISTIC & ActuaL & CONFORM & NONCONFORM & & OOLS / NOTES \\
\hline \multicolumn{7}{|c|}{ Item 4 - A.2 Internal Sodiun Check } \\
\hline & (a) Date of entry in master $\log 9-1-20$. & - & Bpte & & \multirow{2}{*}{\multicolumn{2}{|c|}{$9-1-70$}} \\
\hline & & & & & & \\
\hline \multicolumn{7}{|c|}{ B.1 Radiation Survey } \\
\hline & (a) Date of entry in master $\log 7-29-70$. & 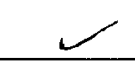 & \multirow{2}{*}{$B A A$} & & \multicolumn{2}{|c|}{$7 / 29 / 70$} \\
\hline & & & & \multicolumn{2}{|c|}{ (2) } \\
\hline & & & & \multirow{2}{*}{\multicolumn{2}{|c|}{ 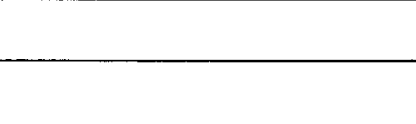 }} \\
\hline & & & & & & \\
\hline & & & & \multicolumn{2}{|c|}{$x^{2}$} \\
\hline & & & & & \multirow{2}{*}{\multicolumn{2}{|c|}{ 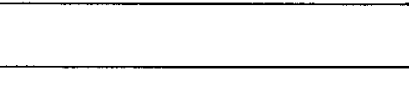 }} \\
\hline & & & & & \\
\hline & & & & \multicolumn{2}{|c|}{ 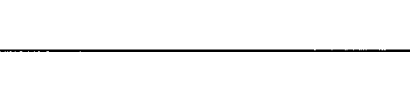 } \\
\hline & & & & \multicolumn{2}{|c|}{$x^{2}$} \\
\hline & & & & \multicolumn{2}{|c|}{ 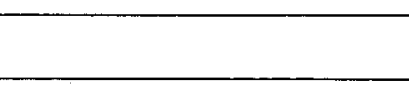 } \\
\hline & & & & & \multirow{2}{*}{\multicolumn{2}{|c|}{ 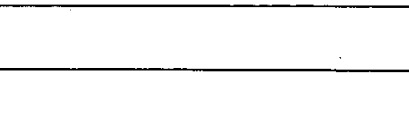 }} \\
\hline & & & & & \\
\hline & & & & \multicolumn{2}{|c|}{+2} \\
\hline & & & & & \\
\hline & & & & & & \\
\hline & & & & & & \\
\hline
\end{tabular}


FORM INC $573(4-69)$ QA

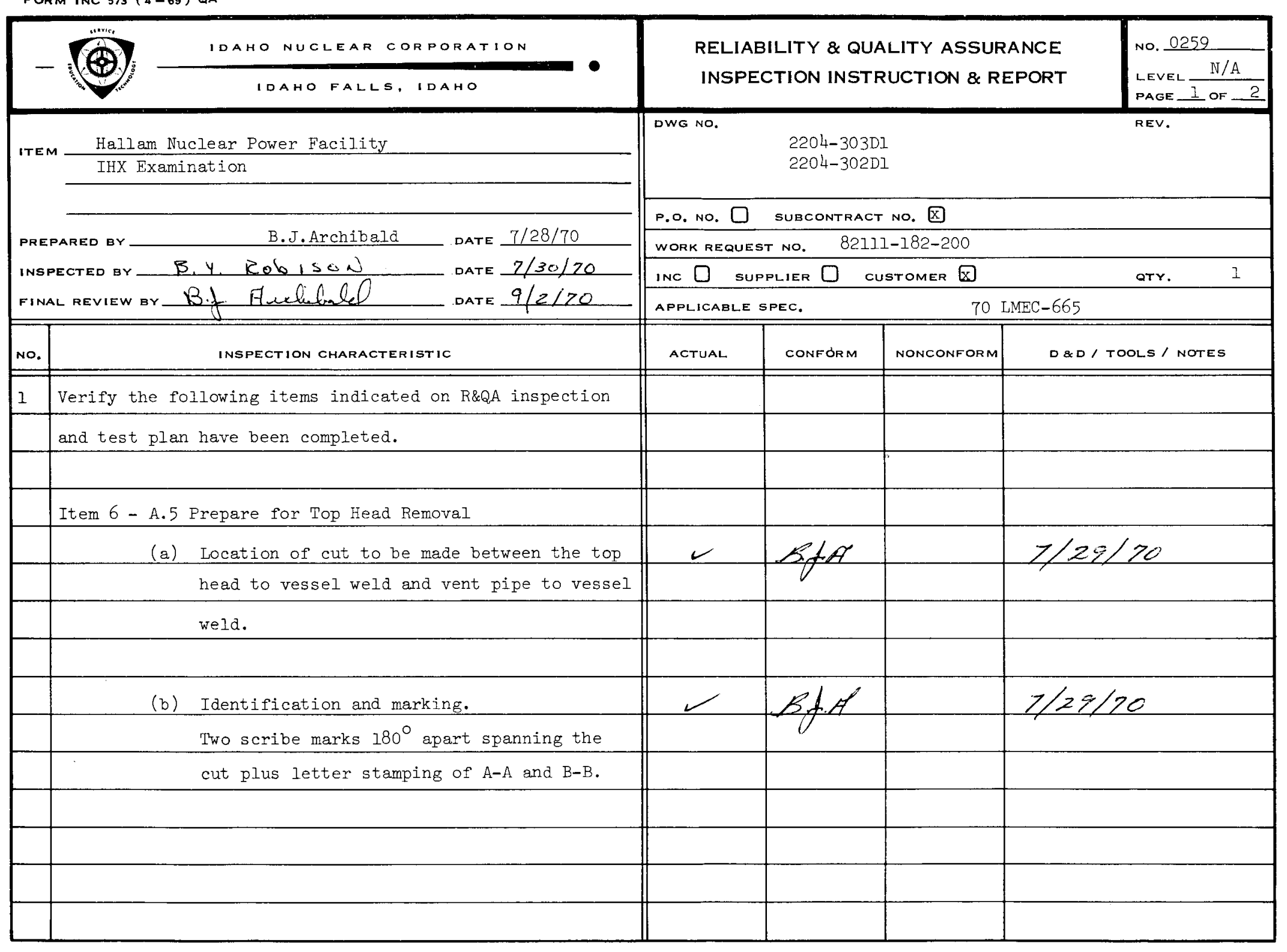


FORM INC 573-A (4-69) QA

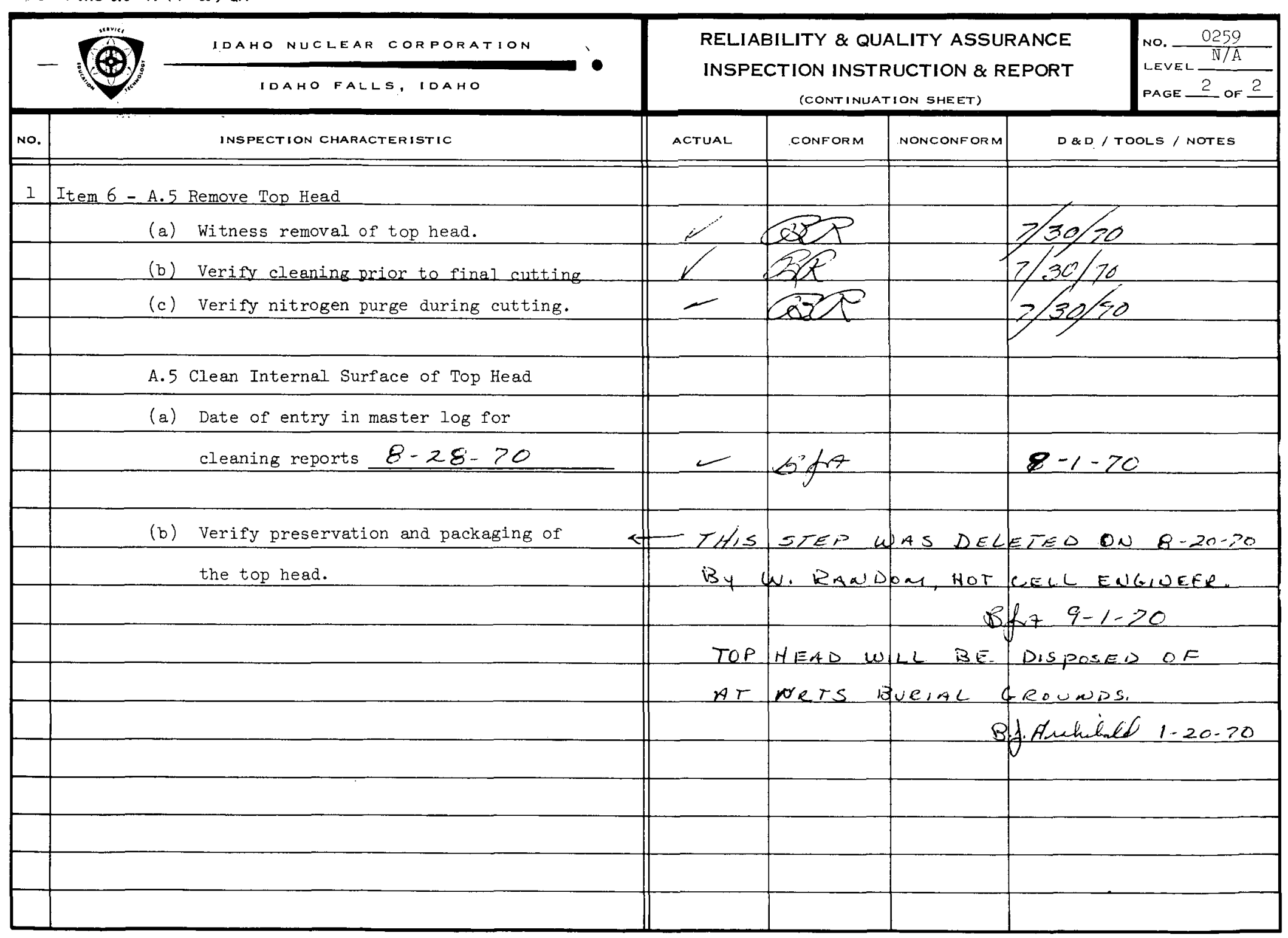


FORM INC $573(4-69)$ OA

\begin{tabular}{|c|c|c|c|c|c|c|}
\hline & (69) $\frac{\text { IDAHO NUCLEAR COTPORATION }}{\text { IDAHOFALLS, IDAHO }}$ & \multicolumn{4}{|c|}{$\begin{array}{l}\text { RELIABILITY \& QUALITY ASSURANCE } \\
\text { INSPECTION INSTRUCTION \& REPORT }\end{array}$} & $\begin{array}{l}\text { NO. } \frac{0280}{\mathrm{~N} / \mathrm{A}} \\
\text { LEVEL } \frac{\mathrm{N}}{\text { I OF I }}\end{array}$ \\
\hline \multirow{4}{*}{\multicolumn{2}{|c|}{ 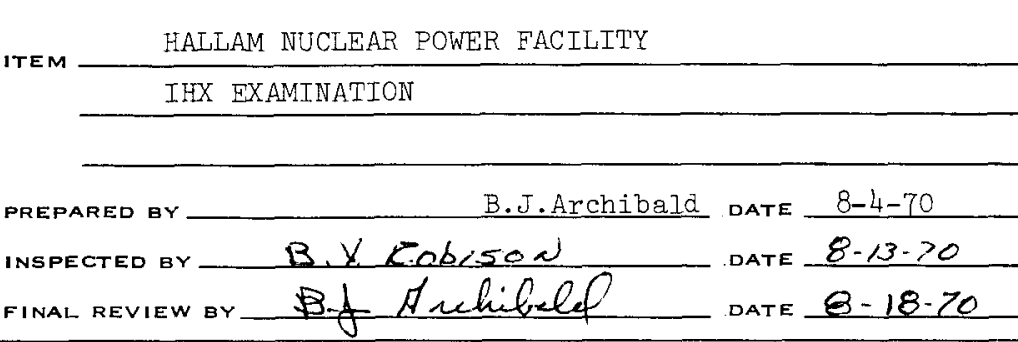 }} & \multicolumn{4}{|c|}{\begin{tabular}{|l} 
DWG NO. \\
$\begin{aligned} 2204-303 D I \\
2204-302 D I\end{aligned}$
\end{tabular}} & REV. \\
\hline & & \multicolumn{5}{|c|}{ P.o. No. $\square$ subcontract no. $\bigotimes$} \\
\hline & & \multicolumn{5}{|c|}{ WORK REQUEST NO. $82111-182-200$} \\
\hline & & \multicolumn{5}{|c|}{ inc 0 Supplier $\square$ customer $\otimes$} \\
\hline no. & INSPECTION CHARACTERISTIC & ACtuAL & CONFORM & NONCONFORM & & OLS/ NOTES \\
\hline \multirow[t]{2}{*}{1} & Verify the following item indicated on $R \& Q A$ Inspection & & & & & \\
\hline & and Test Plan has been completed: & & & & & \\
\hline \multicolumn{7}{|c|}{ Item $7-$ A.3 Helium Leak Check Top Tubes } \\
\hline & (a) Date of calibration on the helium & & & & & \\
\hline & standard leak rate: $\mid z-24-61$ & & & & $8 / 2$ & \\
\hline & (b) Witness helium leak check. & & & & $8 / 3$ & \\
\hline & (c) Verify recalibration of leak detector & & & & & \\
\hline & every 4 and 8 hours of operation. & & ) & & $5 / 12$ & \\
\hline & (d) Date of entry in master log for leak & & & & & \\
\hline & test reports: $8 /, 5<<0$ & & & & $8 / 13$ & \\
\hline & & & & & & \\
\hline & & & & & & \\
\hline & & & & & & \\
\hline & & & & & & \\
\hline
\end{tabular}


FORM INC $573(4-69)$ QA

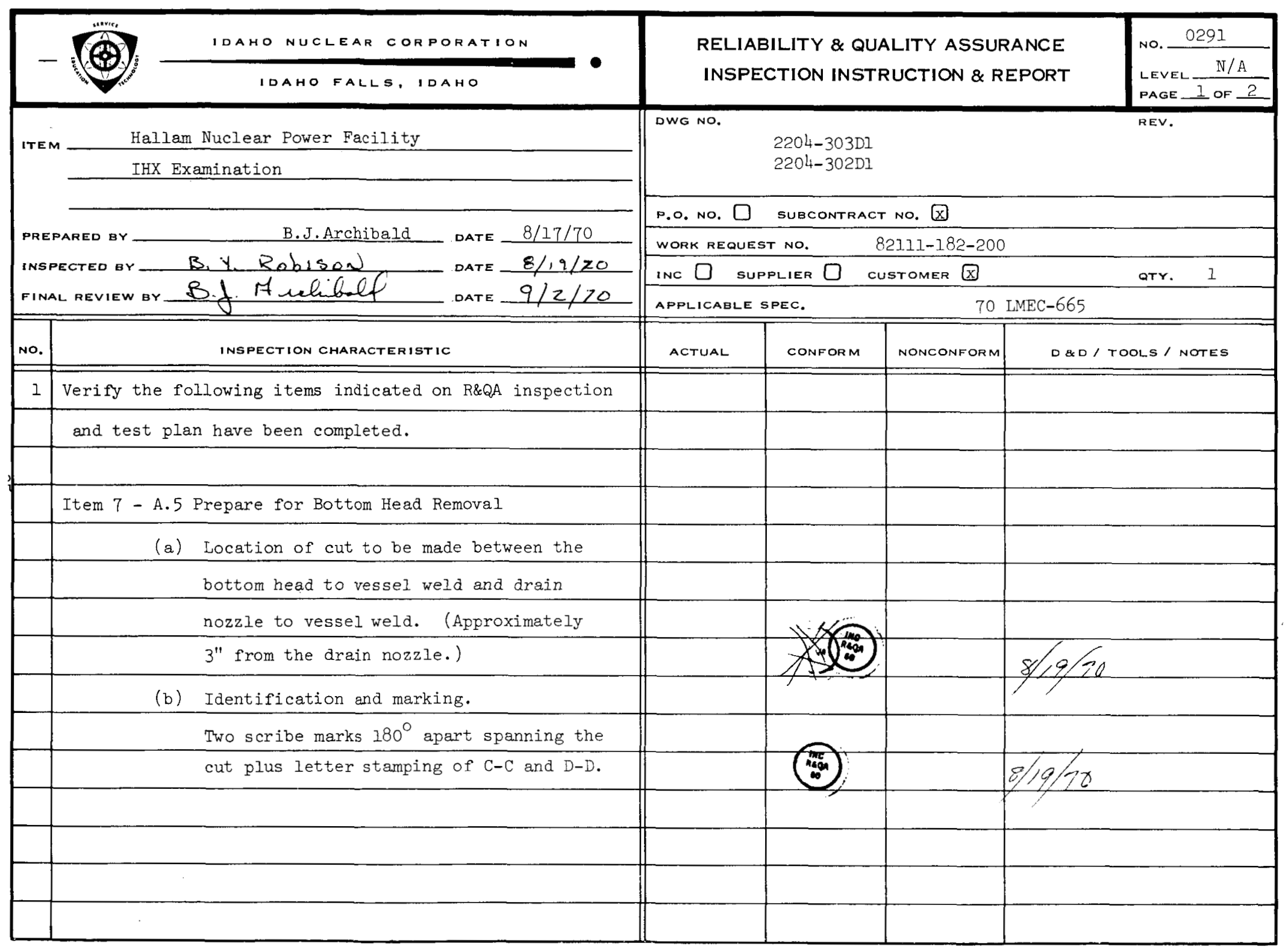


FORM INC 573-A (4-69) OA

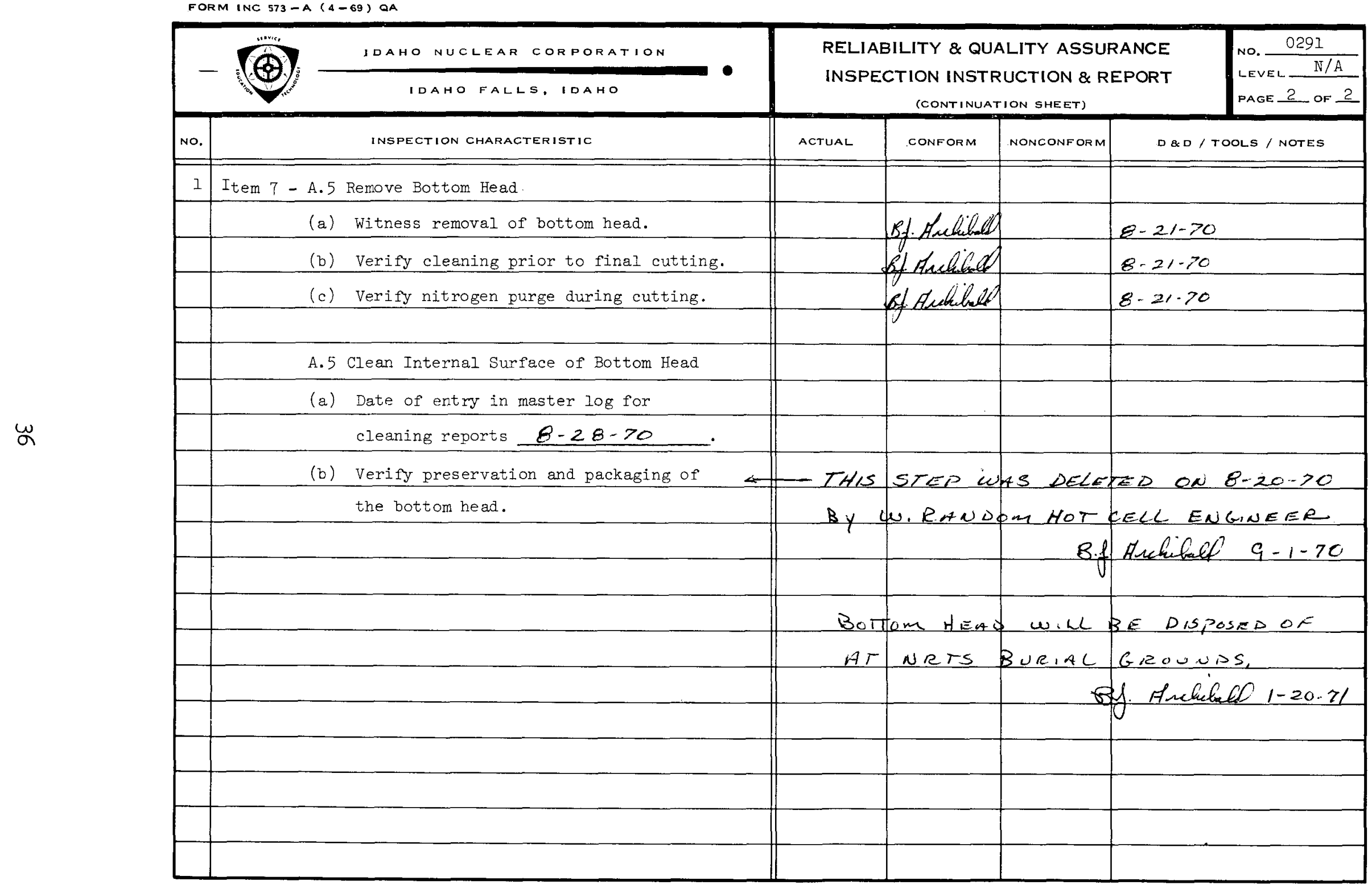


FORM INC $573(4-69)$ QA

\begin{tabular}{|c|c|c|c|c|c|}
\hline- & IDAHONUCLEAR CORPORATION & \multicolumn{3}{|c|}{$\begin{array}{l}\text { RELIABILITY \& QUALITY ASSURANCE } \\
\text { INSPECTION INSTRUCTION \& REPORT }\end{array}$} & $\begin{array}{l}\text { NO. } \frac{0295}{\mathrm{~N} / \mathrm{A}} \\
\text { LEVEL } \frac{\mathrm{N}}{1 \text { OF }-2}\end{array}$ \\
\hline \multirow{5}{*}{\multicolumn{2}{|c|}{ 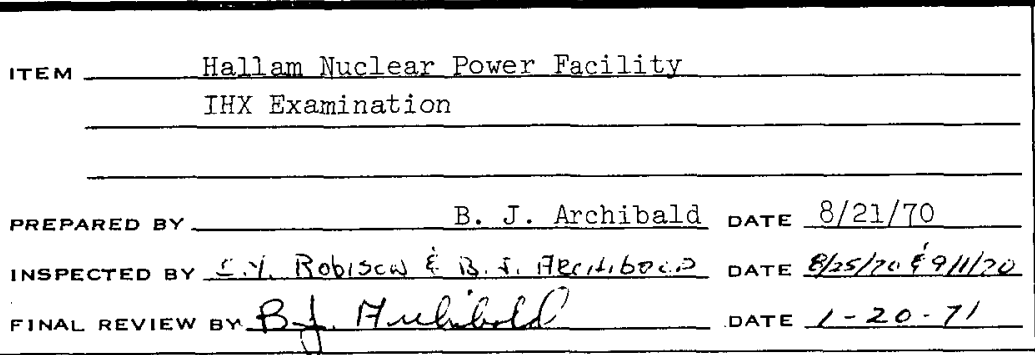 }} & \multicolumn{4}{|c|}{$\begin{array}{l}\text { OWG NO. } \\
\qquad \begin{aligned} 2204-303 D 1 \\
2204-302 D 1\end{aligned}\end{array}$} \\
\hline & & \multicolumn{4}{|c|}{ P.O. NO. $\square$ Subcontract no. $\mathrm{x}$} \\
\hline & & \multicolumn{4}{|c|}{ WORK REQUEST NO. $82111-182-200$} \\
\hline & & \multicolumn{4}{|c|}{ inc $\square$ supplier $\square$ customer $\square$} \\
\hline & & \multicolumn{4}{|c|}{ APPLICABLE SPEC. $\quad 70$ LMEC-665 } \\
\hline No. & INSPECTION CHARACTERISTIC & ACTUAL & CONFORM & NONCONFORM & D\&D/TOOLS/ NOTES \\
\hline \multirow[t]{2}{*}{1} & Verify the following items inaicated on R\&QA & & & & \\
\hline & inspection and test plan have been completed. & & & & \\
\hline & Item 5 - A.4 Primary Nozzles (Removal) & $-(T, 1$, & S STEP & JWA $\triangle D E L$ & $=T E D$ ONi $8-20.70$ \\
\hline & (a) Verify location of the areas to be cut & By & W. Rmas & $\mathrm{HOC}$ & CELL ENGWEER \\
\hline & and identify ing marks. & & & & $8+49-1-70$ \\
\hline & (b) Verify preservation and packaging of & $=w<c$ & BE OISp & $0: E 0$ OF & Ar NeTS Bueinc \\
\hline & removed nozzles. & GROL: & UDs & A-atid & $1-20-21$ \\
\hline & (c) Internal visual examination reports, & & & & \\
\hline & date of entry in master $\log$ & & & & \\
\hline & (d) Nitrogen purge reports, & & & & \\
\hline & date of entry in master $\log$ & & & & \\
\hline & & & & & \\
\hline & & & & & \\
\hline & & & & & \\
\hline
\end{tabular}


FORM INC $573-A(4-69)$ QA

\begin{tabular}{|c|c|c|c|c|c|}
\hline \multirow{2}{*}{ No. } & \multirow{2}{*}{ 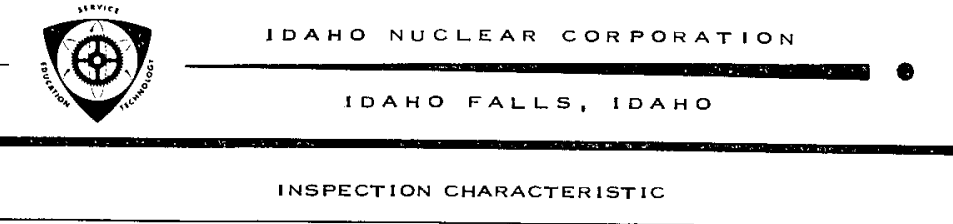 } & \multicolumn{4}{|c|}{$\begin{array}{l}\text { RELIABILITY \& QUALITY ASSURANCE } \\
\text { INSPECTION INSTRUCTION \& REPORT } \\
\text { (CONTINUATION SHEET) }\end{array}$} \\
\hline & & ActuAal & CONFORM & NONCONFORM & $\begin{array}{l}\text { NO. } \frac{0295}{\mathrm{~N} / \mathrm{A}} \\
\text { LEVEL } \frac{2}{2} \text { OF } 2 \\
\text { OOLS / NOTES }\end{array}$ \\
\hline & Item 5 - A.4 Secondary Nozzles (Removal) & & & & \\
\hline & (a) Verify location of the areas to be cut & & 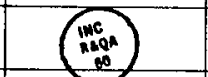 & & $8 / 25 / 70$ \\
\hline & and identifying marks. & & & & \\
\hline & (b) Verify preservation and packaging of & $\omega, L C$ & $B E D I S A$ & paises of & AT NETS \\
\hline & removed nozzles. & $B \cup B$ & & - D.s & Andiuber $1-20.71$ \\
\hline & (c) Internal visual examination reports, & & & & \\
\hline & date of entry in master $\log 8-31-70$ & 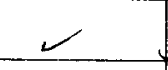 & E. Hubinted & & $9-1-70$ \\
\hline & (d) Nitrogen purge reports, & & 7 & & \\
\hline & date of entry in master $\log 8-31 \cdot 70$. & $\sim$ & Bitheraloto & & $9-1-20$ \\
\hline & & & V & & \\
\hline & Item 5-B NDT of External Piping & TH,S & ster & WAS DEL & $\angle E, \Delta B y$ \\
\hline & (a) Perform liquid penetrant examinations & $w, A$ & $A N D$ & HOT CEL & C. ENGAEE \\
\hline & on nozzles to shell welds. & & & Bef if at & eibed \\
\hline & (b) Verify photographs of the liquid & & & $v_{1}-20$ & -21 \\
\hline & penetrant examinations. & & & & \\
\hline & & & & & \\
\hline & C-l Metallography of Piping Welds & TH & STEP & was & DELETED $B_{Y}$ \\
\hline & (a) Verify sample identification and marking. & $\omega_{i}$ & RANDOM & HoT C B & LL ENGIDEER \\
\hline & (b) Verify date that reports are filed in & & & $\beta-d$ & Henkibuld \\
\hline & the master log & & & & $-20-21$ \\
\hline
\end{tabular}


FORM INC $573(4-69)$ QA

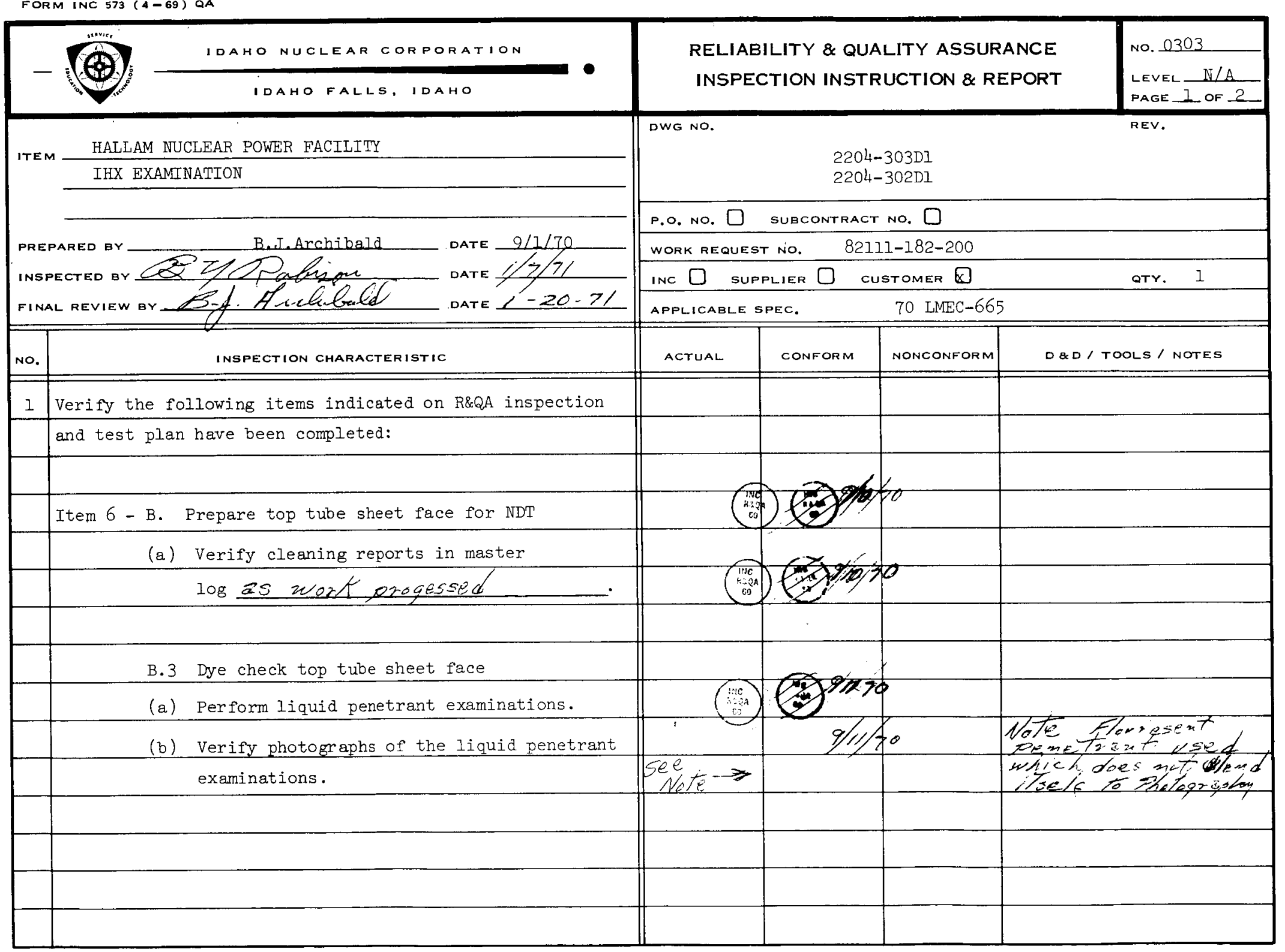


FORM INC $573-A(4-69)$ QA

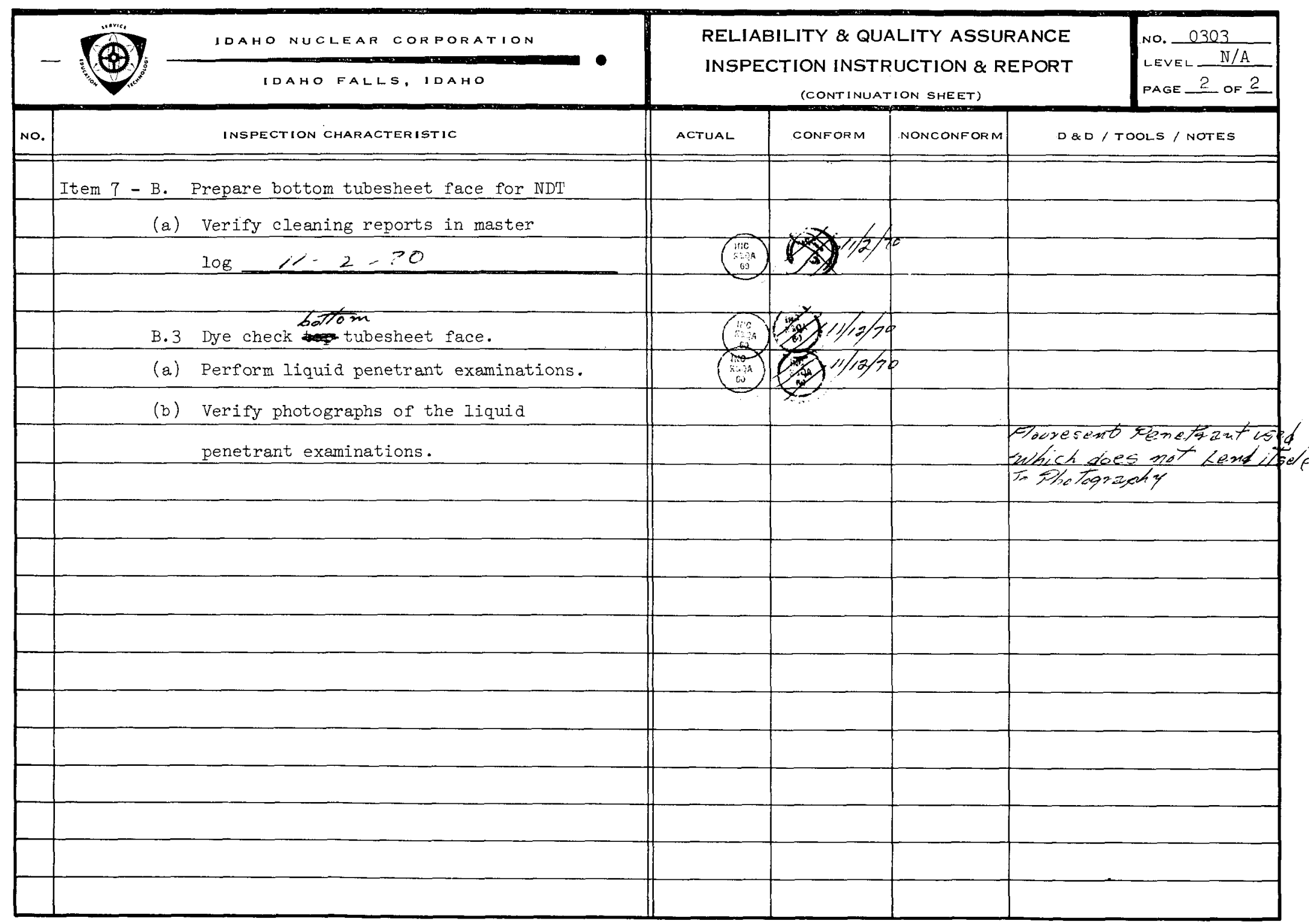


FORM INC $373(4-69)$ QA

\begin{tabular}{|c|c|c|c|c|c|c|}
\hline \multicolumn{2}{|r|}{ - (89) IDAHONUCLEAR CORPORATION } & \multicolumn{4}{|c|}{$\begin{array}{l}\text { RELIABILITY \& QUALITY ASSURANCE } \\
\text { INSPECTION INSTRUCTION \& REPORT }\end{array}$} & NO. $\frac{0304}{\text { LEVEL } \frac{N / A}{1 \text { OF } 4}}$ \\
\hline \multirow{3}{*}{\multicolumn{2}{|c|}{ 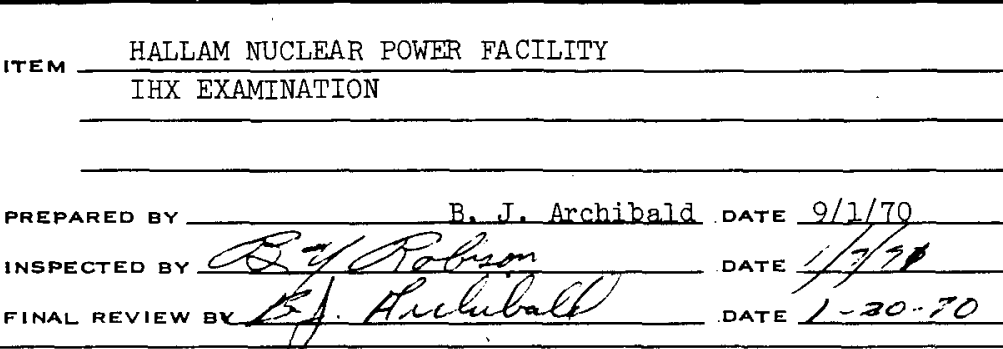 }} & \multicolumn{5}{|c|}{$\begin{array}{l}\text { DWG NO. } \\
\qquad \begin{array}{l}2204-303 D 1 \\
2204-302 D 1\end{array}\end{array}$} \\
\hline & & \multicolumn{5}{|c|}{ P.O. NO. $\square$ SUBCONTRACT NO. $\otimes$} \\
\hline & & INC $\square$ & EC. & STOMER Q & +2 & aTY. 1 \\
\hline No. & INSPECTION CHARACTERISTIC & ACTUAL & CONFORM & NONCONFORM & D \& & DLS / NOTES \\
\hline \multirow[t]{2}{*}{1} & Verify the following items indicated on R\&QA inspection & & & & & \\
\hline & and test plan have been completed: & & & & & \\
\hline \multicolumn{7}{|c|}{ Item 9 - A. 7 Cut tubes above both tubesheets. } \\
\hline & (a) Verify location of areas to be cut. & & & & $10 / 5$ & - \\
\hline & (b) Verify identification and marking. & & & $\leftarrow \% \rho$ & $10 / 5 / 50$ & \\
\hline \multicolumn{7}{|c|}{ Item 10 - A.8 Bottom tubesheet removal } \\
\hline & (a) Verify location of area to be cut. & & & & \multicolumn{2}{|c|}{$C-C \& D-D$} \\
\hline \multicolumn{7}{|c|}{ (b) Verify identification and marking. } \\
\hline \multicolumn{7}{|c|}{ (c) Verify cleaning prior to final cutting. } \\
\hline & B. NDT bottom tubesheet to shell welds & & & & \multicolumn{2}{|c|}{$\begin{array}{l}\text { Tube shegt to sheil weid } \\
\text { secondary side }\end{array}$} \\
\hline & (a) Verify visual examination reports in & & & & \multicolumn{2}{|c|}{1} \\
\hline & master $\log , \angle<<->0$ & & & & \multicolumn{2}{|c|}{$18 / 12 / 70$} \\
\hline
\end{tabular}




\begin{tabular}{|c|c|c|c|c|c|}
\hline \multirow{2}{*}{ No. } & \multirow{2}{*}{$\frac{\text { idaho Nuclear corporation }}{\text { IDAho falls. IDAHo }}$} & \multicolumn{4}{|c|}{$\begin{array}{l}\text { RELIABILITY \& QUALITY ASSURANCE } \\
\text { INSPECTION INSTRUCTION \& REPORT } \\
\text { (CONTINUATION SHEET) }\end{array}$} \\
\hline & & ActuAl & CONFORM & nonconform & DED / TOOLS / NOTES \\
\hline & (b) Perform liquid penetrant examinations. & & $(10)$ & & No releyanting \\
\hline & (c) Verify photographs of the liquid penetrant & & & & Primany side \\
\hline & examinations. & & & & 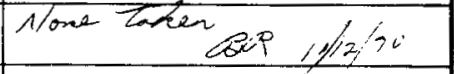 \\
\hline & Item $10-$ A. 8 Section bottom tube sheet & & & & \\
\hline & (a) Verify location of areas to be cut. & & $\int 2 / 1 / 70$ & & Samples dailled as \\
\hline & (b) Verify identification and marking. & & $j / 3 / 1 / 30$ & & $\begin{array}{l}\text { zegured ins work } \\
\text { progessed }\end{array}$ \\
\hline & (c) Verify preservation and packaging of & 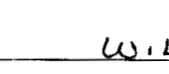 & $B E O$ & SPOSED & OF AT NRTS \\
\hline & remaining material. & $B \cup$ & a. & kounds, & Bf. Awhelele, 1-20.21 \\
\hline & B.4 Radiograph tubesheet sections & TH, & tep & U.45 DEd & $k \in \pi, D B$ \\
\hline & (a) Use Form INC-1802 for reporting. & $\omega$. & Dom & Hor CES & $K$ Lex. \\
\hline & & & & B... Af & whibed 1-20-21 \\
\hline & C.I Thubesheet metallography & & & & \\
\hline & (a) Verify sample identification and marking. & & & & \\
\hline & (b) Verify that reports are filed in the & & 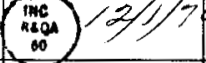 & & \\
\hline & master log reports filed as data ob & ined & & & \\
\hline & & & & & \\
\hline & C.2 Corrosion sample analyses & $T H, S$ & STEP & HAS DE & 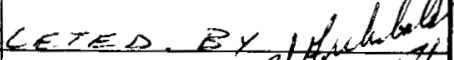 \\
\hline & & $\omega, 2$ & WDOM Ad & $d r \operatorname{cec} \leq t$ & NGIa)eER $1^{-20}$ \\
\hline
\end{tabular}


FORM INC 573-A (4-69) QA

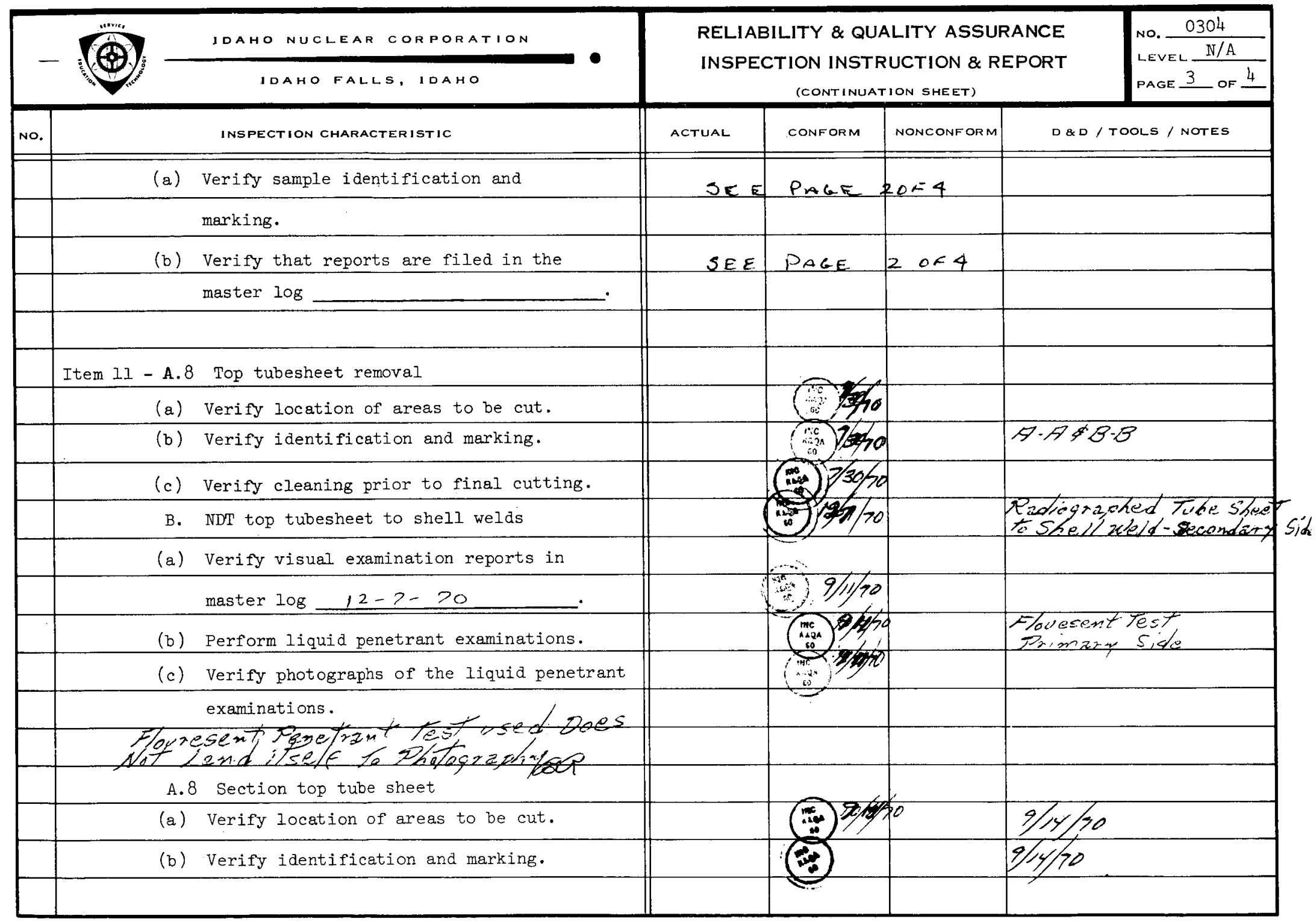


FORM INC 573-A (4-69) QA

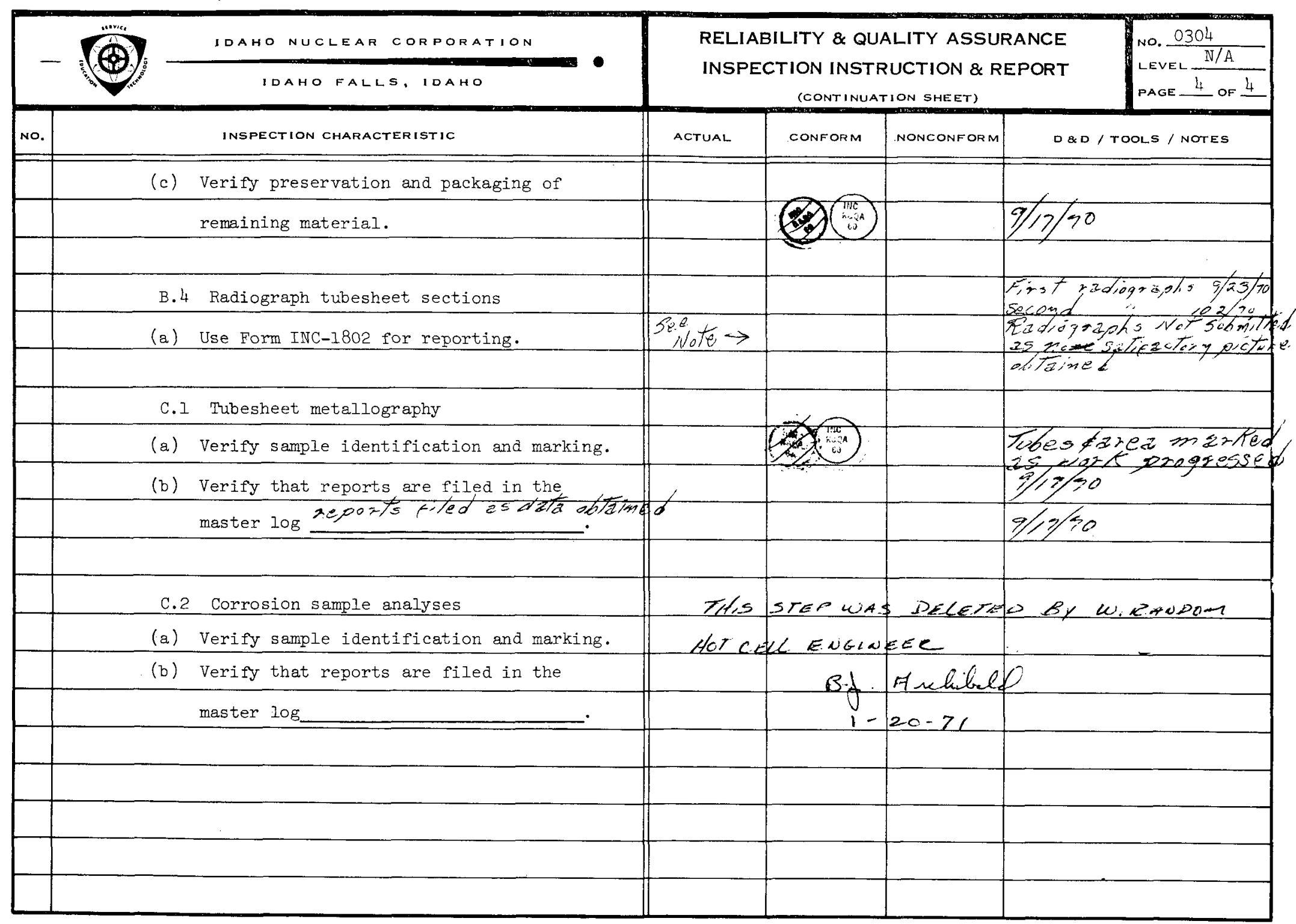


IDAHO NUCLEAR CORPORATION

\section{RADIOGRAPHIC REVIEW REPORT}

PAGE $<$ of 2

DATE $12-\not X-70$

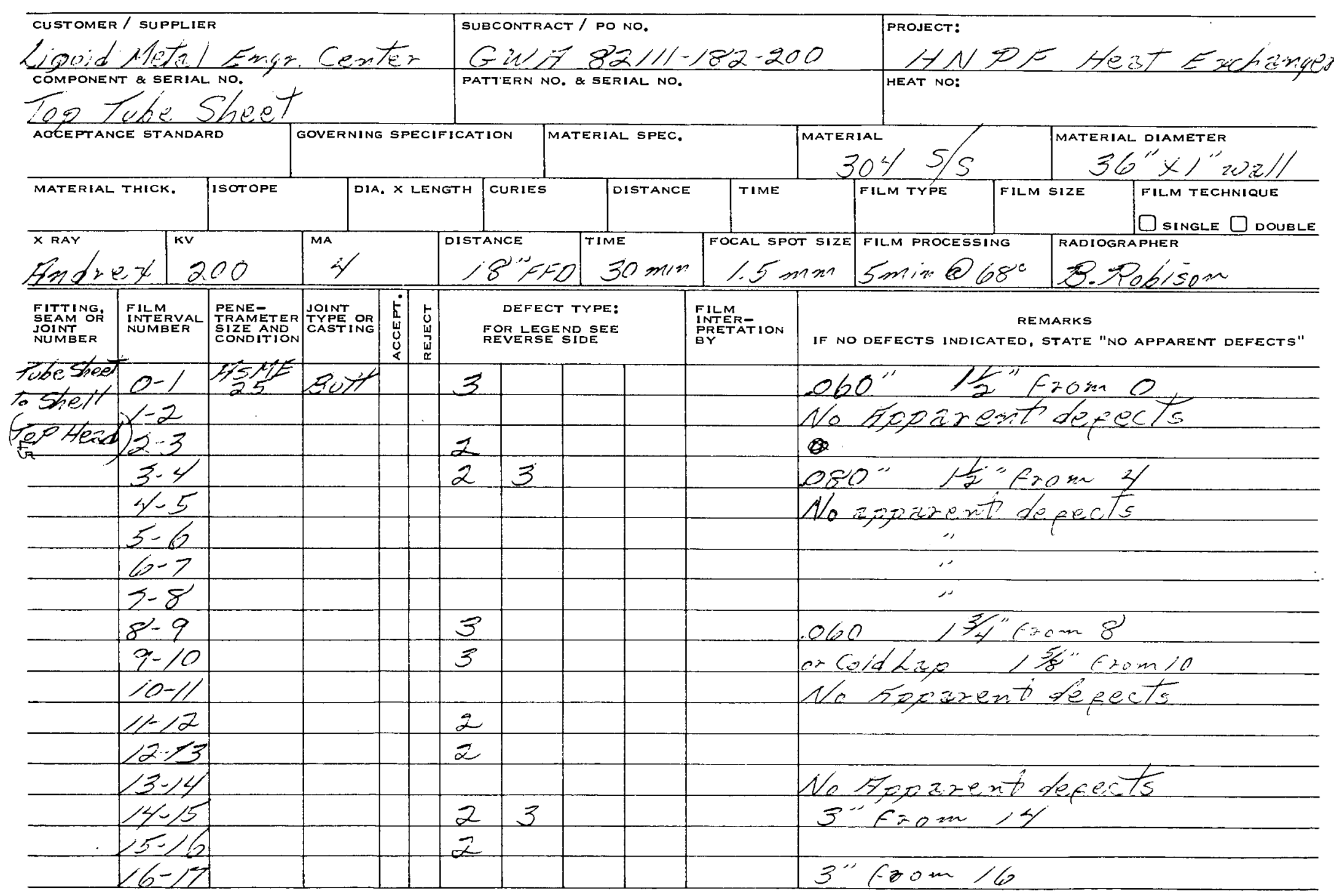


1. JOINT • TYPE

$\begin{array}{ll}\text { CONSUMABLE INSERT } & \text { EB } \\ \text { BACKING RING } & \text { BR } \\ \text { SOCKET WELD } & \text { SOC } \\ \text { SEAL WELD } & \text { SEAL } \\ \text { FILLET WELD } & \text { FW }\end{array}$

3. DEFECT IDENTIFICATION

$\begin{array}{lc}\text { SLAG } & 1 \\ \text { POROSITY } & 2 \\ \text { LACK OF FUSION } & 3 \\ \text { LACK OF PENETRATION } & 4 \\ \text { TUNGSTEN } & 5 \\ \text { CRACKS } & 6 \\ \text { UNCONSUMED INSERT } & 7 \\ \text { OXIDATION } & 8 \\ \text { BURN THRU } & 9 \\ \text { ARC STRIKES } & 10 \\ \text { WELD SPLATTER } & 11 \\ \text { UNDERCUT } & 12\end{array}$

2. CASTING

$$
\text { C ST G }
$$


IDAHO NUCLEAR CORPORATION RADIOGRAPHIC REVIEW REPORT

\section{CUSTOMER / SUPPLIER}

COMPONENT \& SERIAL NO.

\section{SUBCONTRACT / PO NO.}

W HA 82111-182-200 PATTERN NO. \& SERIAL NO.
PAGE 2 OF $\mathcal{2}$

DATE $\angle 2-4 \angle->0$

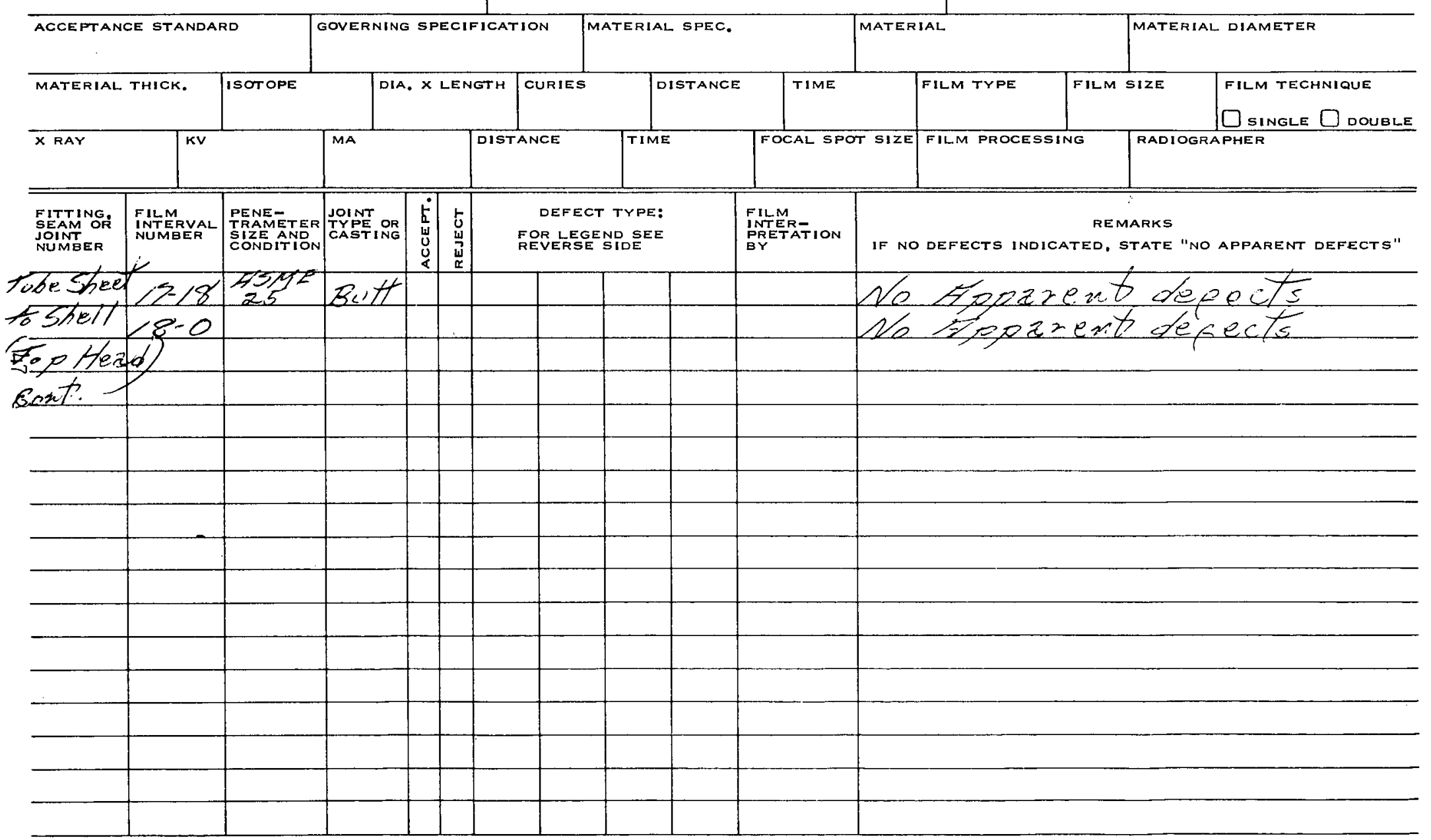


1. JOINT - TYPE

CONSUMABLE INSERT

BACKING RING

SOCKET WELD

SEAL WELD

FILLET WELD
2. CASTING

CST G

3. DEFECT IDENTIFICATION

$\begin{array}{lc}\text { SLAG } & 1 \\ \text { POROSITY } & 2 \\ \text { LACK OF FUSION } & 3 \\ \text { LACK OF PENETRATION } & 4 \\ \text { TUNGSTEN } & 5 \\ \text { CRACKS } & 6 \\ \text { UNCONSUMED INSERT } & 7 \\ \text { OXIDATION } & 8 \\ \text { BURN THRU } & 9 \\ \text { ARC STRIKES } & 10 \\ \text { WELD SPLATTER } & 11 \\ \text { UNDERCUT } & 12\end{array}$

$\begin{array}{ll}\text { CRATER PITS } & 13 \\ \text { CONCAVITY } & 14 \\ \text { CONVEXITY } & 15 \\ \text { MELT-THRU } & 16 \\ \text { SURFACE } & 17 \\ \text { SHRINKAGE } & 18 \\ \text { HOT TEAR } & 19 \\ \text { SAND } & 20 \\ \text { GAS } & 21 \\ \text { CHAPLETS } & 22 \\ \text { COLD SHUT } & 23 \\ \text { FILM ARTIFACT } & 24\end{array}$


APPENDIX B

SELECTED PLANNING DOCUMENTS 


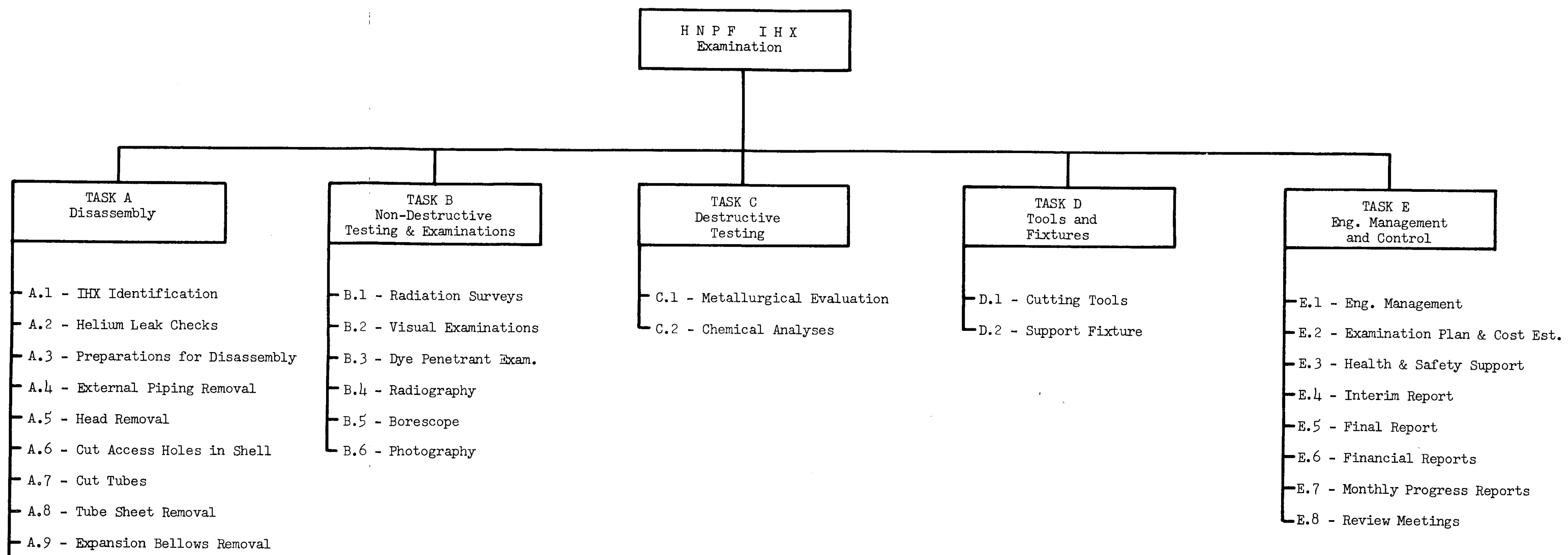




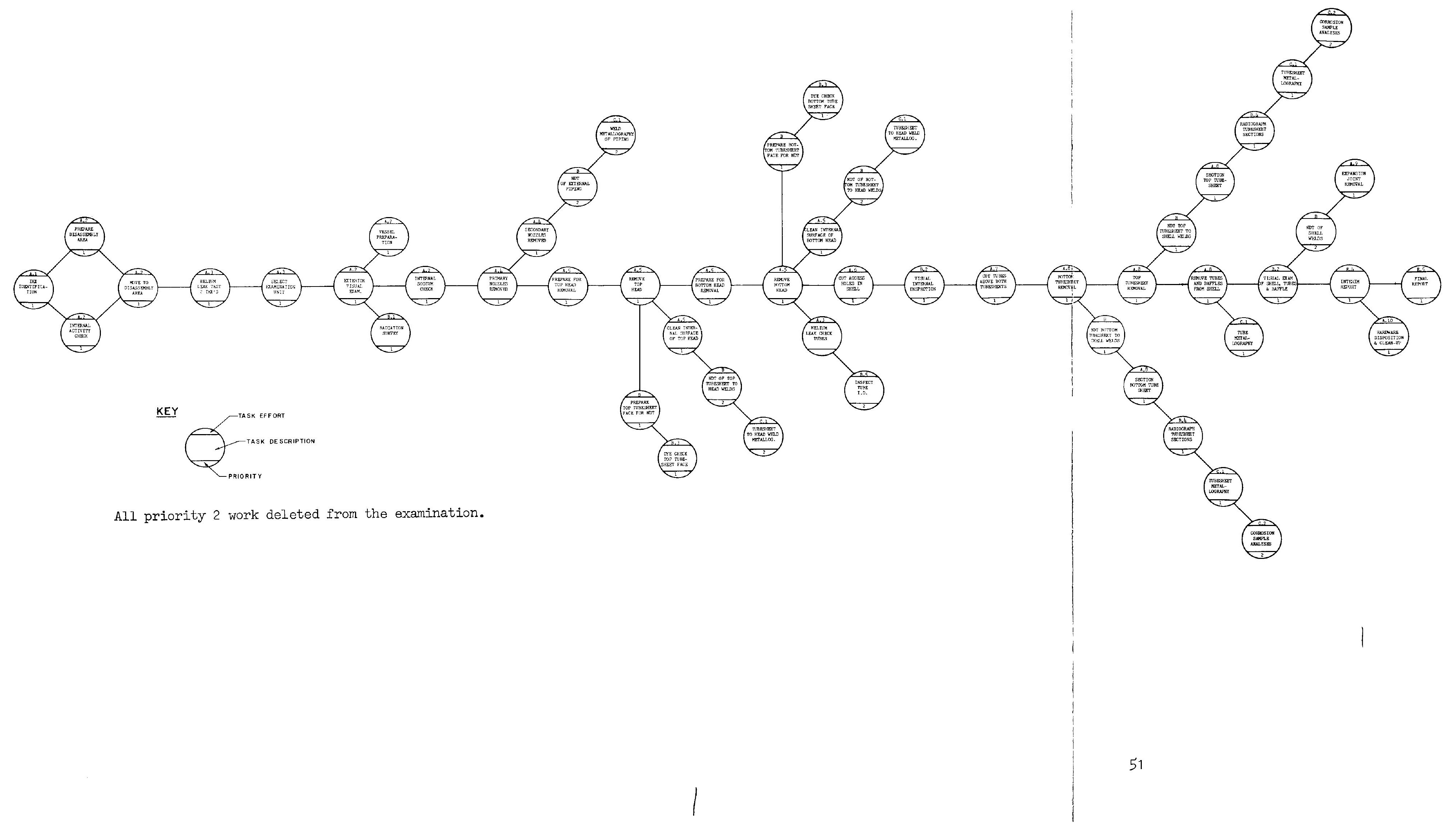


PROJECT SCHEDULE

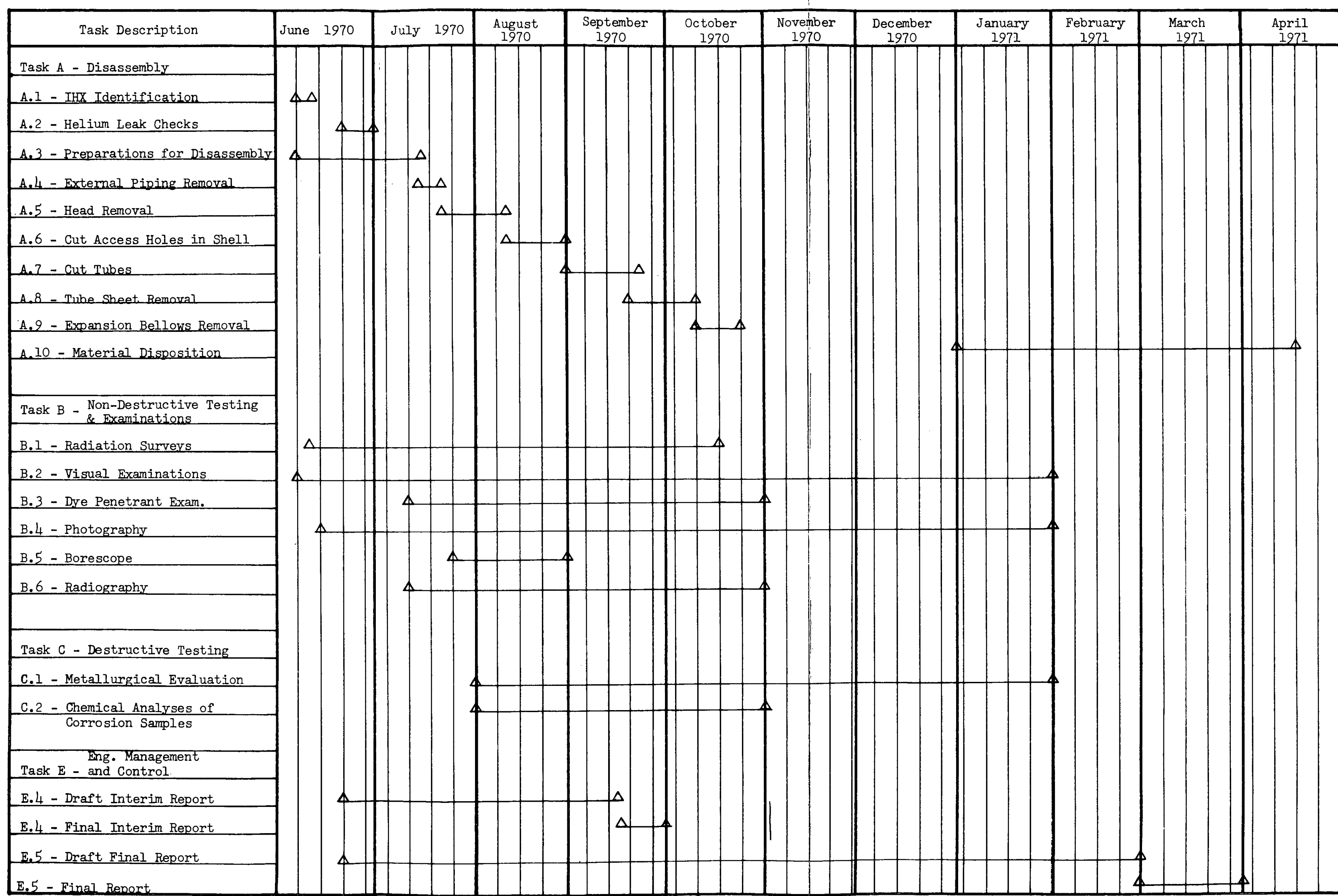

Goug Paif TAN Operations

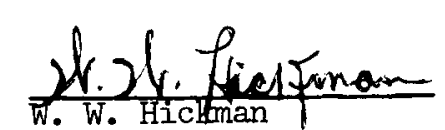
Metailurgy and Hot Cell Branch 